\title{
Ammonia fluxes in relation to cutting and fertilization of an intensively managed grassland derived from an inter-comparison of gradient measurements
}

\author{
C. Milford ${ }^{1, *}$, M. R. Theobald ${ }^{1}$, E. Nemitz ${ }^{1}$, K. J. Hargreaves ${ }^{1}$, L. Horvath ${ }^{2}$, J. Raso ${ }^{2}$, U. Dämmgen ${ }^{3}$, A. Neftel ${ }^{4}$, \\ S. K. Jones ${ }^{1,4}$, A. Hensen ${ }^{5}$, B. Loubet ${ }^{6}$, P. Cellier ${ }^{6}$, and M. A. Sutton ${ }^{1}$ \\ ${ }^{1}$ Centre for Ecology and Hydrology (Edinburgh Research Station), Bush Estate, Penicuik, Midlothian, EH26 0QB, UK \\ ${ }^{2}$ Institute of Atmospheric Physics, P.O. Box 39, 1675 Budapest, Hungary \\ ${ }^{3}$ Institut für Agrarökologie, Bundesforschungsanstalt für Landwirtschaft (FAL), Bundesallee 50, \\ 38116 Braunschweig, Germany \\ ${ }^{4}$ Agroscope Reckenholz-Tänikon Research Station ART, Reckenholzstrasse 191, 8046 Zurich, Switzerland \\ ${ }^{5}$ Energy research Centre of the Netherlands (ECN), Postbus 1, 1755 ZG Petten, The Netherlands \\ ${ }^{6}$ Institut National de la Recherche Agronomique (INRA), UMR Environnement et Grandes Cultures, \\ Thiverval-Grignon, 78850, France \\ "now at: Institute of Earth Sciences “Jaume Almera”, CSIC, C/Lluis Solé i Sabarís s/n, Barcelona, 08028, Spain
}

Received: 5 September 2008 - Published in Biogeosciences Discuss.: 4 December 2008

Revised: 23 April 2009 - Accepted: 10 May 2009 - Published: 15 May 2009

\begin{abstract}
Quantification of ammonia $\left(\mathrm{NH}_{3}\right)$ landatmosphere exchange is required for atmospheric modelling and assessment of nitrogen deposition, yet flux measurement methods remain highly uncertain. To address this issue, a major inter-comparison of ammonia fluxes over intensively managed grassland was conducted during the GRAMINAE Integrated Experiment held in Braunschweig, Germany. In order to provide a robust dataset of ammonia exchange with the vegetation, four independent continuous flux gradient systems were operated. Three independently operated continuous wet denuders systems (AMANDA) were compared with a Wet Effluent Diffusion Denuder (mini-WEDD) system. Measurements were made at two distances from an adjacent livestock farm, allowing effects of advection to be quantified in a real landscape setting. Data treatment included filtering for instrument failure, disturbed wind sectors and unsuitable micrometeorological conditions, with corrections made for storage and advection errors.
\end{abstract}

The inter-comparison demonstrated good agreement in measured ammonia concentrations and fluxes (relative standard error $<20 \%$ ) for some periods, although the performance of the ammonia analyzers were variable, with much

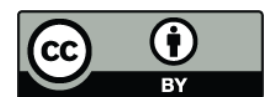

Correspondence to: C. Milford (cmilford@inm.es) poorer agreement on particular days. However, by using four systems, the inter-comparison was able to provide a robust mean estimate of continuous ammonia fluxes through the experiment. The observed fluxes were: a) small bi-directional fluxes prior to cutting (-64 to $42 \mathrm{ng} \mathrm{NH}_{3} \mathrm{~m}^{-2} \mathrm{~s}^{-1}$ ), b) larger diurnally-varying emissions following cutting ( -49 to $703 \mathrm{ng} \mathrm{NH}_{3} \mathrm{~m}^{-2} \mathrm{~s}^{-1}$ ) and c) much larger emissions following fertilizer application (0 to $3820 \mathrm{ng} \mathrm{NH}_{3} \mathrm{~m}^{-2} \mathrm{~s}^{-1}$ ). The results are a salutary reminder of the uncertainty in unreplicated ammonia flux measurements, while the replication of the present study provides a uniquely robust dataset for the evaluation of ammonia exchange processes. It is clear that consistently reliable determination of ammonia concentrations remains the major measurement challenge.

\section{Introduction}

Measurements of ammonia exchange with vegetation using micrometeorological methods have been conducted since the 1970s (e.g. Denmead et al., 1974, 1976; Dabney and Bouldin, 1985; Harrison et al., 1989; Flechard et al., 1998; Warland et al., 2001; Phillips et al., 2004). The measurements have been conducted over a range of agricultural systems as well as semi-natural systems (e.g. Erisman and Wyers, 1993; Sutton et al., 1993b; Duyzer, 1994; Nemitz et

Published by Copernicus Publications on behalf of the European Geosciences Union. 
al., 2004), including grasslands (e.g. Horvath 1982; Harper et al., 1983; Horvath et al., 2005). Initially, the motivation for measurement of ammonia was to quantify $\mathrm{N}$ losses from agricultural systems. The first measurements used techniques such as bubblers/acid traps (Denmead et al., 1974), filter packs (Harrison and Kitto, 1990) or denuder tubes (e.g. Ferm 1979). All these methods operated at a time resolution of at least $1 \mathrm{~h}$ and required significant operator effort for changing over samples and off-line analysis. As a consequence, most early measurements were for short fieldcampaigns only, of a few days or weeks (e.g. Sutton et al., 1993b; Duyzer 1994).

As interest in ammonia $\left(\mathrm{NH}_{3}\right)$ as an atmospheric pollutant has grown, so too has the range of measurement techniques available. Developments in continuous measurementtechniques enabled much longer time periods of measurements to be conducted. In particular, the continuous flow denuder (AMANDA) developed by Wyers et al. (1993), achieved the balance between reasonable cost, a wide operating concentration range $\left(0.02-100 \mu \mathrm{g} \mathrm{m}^{-3}\right)$ and on-line analysis with short time resolution ( $<5 \mathrm{~min})$. The AMANDA utilises wet chemistry techniques, stripping ammonia from the air in an acidic capture solution. Other similar instruments have been developed which also operate via wet chemistry methods, for example the Wet Effluent Diffusion Denuder (WEDD) technique (Vecera and Dasgupta, 1991), as well as recent more automated implementations of the AMANDA technique (Trebs et al., 2006; Kruit et al., 2007). Although these techniques have been proven to measure $\mathrm{NH}_{3}$ successfully, there are limitations; in particular they cannot be used for eddy correlation measurements where a sensor with a time response of typically at least $4 \mathrm{~Hz}$ is needed. Shaw et al. (1998), Famulari et al. (2004) and Whitehead et al. (2008) have reported eddy correlation measurements of $\mathrm{NH}_{3}$ fluxes, using a tandem mass spectrometer and tunable diode laser technology, but substantial further developments (and cost reductions) are required before eddy correlation becomes more widely used for $\mathrm{NH}_{3}$ flux measurement.

An alternative micrometeorological flux measurement technique is the relaxed eddy accumulation method (REA). This method has the advantage of not requiring a fast response analyser. REA flux measurements of $\mathrm{NH}_{3}$ have been conducted in recent years (e.g. Neftel et al., 1999; Nemitz et al., 2001a; Meyers et al., 2006) and constitute an area of ongoing research.

Ammonia has been recognised as contributing to eutrophication and acidification of ecosystems (Fangmeier et al., 1994; Krupa et al., 2003). To assess these effects, reliable models of ammonia deposition are needed (Hertel et al., 2006). Currently, there are only crude parameterisations of $\mathrm{NH}_{3}$ exchange present in national and European deposition models and measurements are needed to improve these parameterisations. A European project GRAMINAE (GRassland AMmonia INteractions Across Europe) was therefore initiated to improve quantification and parameterisation of
$\mathrm{NH}_{3}$ exchange with grasslands across Europe (Sutton et al., 2001a, 2007).

In addition to the interest in contrasting ecosystem types (e.g. Horvath et al., 2005; Walker et al., 2006; Kugler et al., 2008), large rates of $\mathrm{NH}_{3}$ emission have been observed following cutting of intensively managed grassland, from the sward itself (Sutton et al., 1997, 2001a; Milford et al., 2001b), with this effect being modelled by Riedo et al. (2002). There is, however, a shortage of studies investigating this emission source, while Bussink et al. (1996) observed the opposite, i.e. an apparent increase in deposition flux immediately after cutting. Emission of $\mathrm{NH}_{3}$ from senescing and decomposing vegetation has also been investigated (Whitehead and Lockyer, 1989; Mannheim, 1997), but this is rather distinct from the enhanced emissions from a regrowing canopy following cutting noted above. Emission of volatile organic compounds (VOCs) has been detected from cut grassland and attributed to a "wounding" of the vegetation (Gouw et al., 1999). Other work has investigated the effect of cutting regimes on the health, yield and species diversity of swards (Smith et al., 1996a, b; Blum et al., 1997; Evans et al., 1998), but not the effect on $\mathrm{NH}_{3}$ exchange. Much research has been conducted on $\mathrm{NH}_{3}$ volatilisation following $\mathrm{N}$ fertilization applied to grassland (e.g. Pain et al., 1989; Thompson et al., 1990a, b, 1991; van der Weerden and Jarvis, 1997; Sommer et al., 2004), but little research has been conducted to quantify the contributions from direct fertilizer emission of $\mathrm{NH}_{3}$ and indirect $\mathrm{NH}_{3}$ emission from the plants themselves.

To address some of these issues, the GRAMINAE Integrated Experiment was held in Braunschweig, Germany, over intensively managed grassland (Sutton et al., 2009b). In order to provide a robust dataset of $\mathrm{NH}_{3}$ exchange with the vegetation, four independent continuous flux gradient systems were operated. Although there have been many intercomparisons of ammonia concentration measurements (e.g. Gras, 1984; Appel et al., 1988; Harrison and Kitto, 1990; Wiebe et al., 1990; Sutton et al., 2001b; Schwab et al., 2007) there have been much fewer inter-comparisons of ammonia flux measurements (Sutton et al., 2000; Whitehead et al., 2008). This paper presents the results of a major intercomparison of continuous $\mathrm{NH}_{3}$ flux measurements over intensively managed grassland. The best estimates of $\mathrm{NH}_{3}$ flux and concentration from this inter-comparison are subsequently used to investigate the effect of cutting and fertilizing on $\mathrm{NH}_{3}$ exchange fluxes. These best estimates of $\mathrm{NH}_{3}$ concentrations and fluxes were also provided to other participants in the experiment as a basis for further analyses, for example in quantifying advection fluxes (Loubet et al., 2009), assessing the relaxed eddy accumulation technique (Hensen et al., 2008), modelling the dynamics of ammonia fluxes (Burkhardt et al., 2009; Personne et al., 2009; Sutton et al., 2009a) and quantifying production of particulate ammonium aerosol (Nemitz et al., 2009a). 


\section{Materials and methods}

\subsection{Micrometeorological theory}

The $\mathrm{NH}_{3}$ flux measurements were made using the aerodynamic gradient method, following the approaches described in Fowler and Duyzer (1989), Monteith and Unsworth (1990) and Sutton et al. (1993). It should be noted that recent research (Flesch et al., 2002; McNaughton, 2006) has questioned the validity and accuracy of the aerodynamic gradient method. The flux $\left(F_{z}\right)$ is calculated from the friction velocity $\left(u_{*}\right)$ and concentration scaling parameter $\left(\chi_{*}\right)$ :

$F_{z}=-u_{*} \chi_{*}$

with emission fluxes denoted as being positive. $\chi_{*}$ is calculated as:

$\chi_{*}=k \frac{d \chi}{d\left[\ln (z-d)-\Psi_{\mathrm{H}}\left(\frac{z-d}{L}\right)\right]}$

where $k$ is von Karman's constant $(=0.41), z$ is height above the surface, $d$ is zero plane displacement, $\chi$ is $\mathrm{NH}_{3}$ concentration and $\Psi_{H}$ is the integrated stability correction function for scalar properties, calculated from the MoninObukhov length $(L)$ according to the description of Sutton et al. (1993). Although $u_{*}$ can be calculated from profiles of windspeed in an equation analogous to Eq. (2), in this instance it was obtained from ultrasonic anemometry using eddy covariance (Moncrieff et al., 1997). $u_{*}$ and all other meteorological parameters were measured by several institutes in the experiment. These estimates have been compared and evaluated by Nemitz et al. (2009b), who provided a consensus dataset for use in the flux calculations here.

The basic calculations of $\mathrm{NH}_{3}$ fluxes derived here assume stationarity and homogeneity of the atmospheric conditions, such that the vertical flux results entirely from turbulent transfer in the vertical and that errors related to local advection (horizontal heterogeneity), storage (temporal instationarity) and chemical production or consumption in the surface layer are ignored. Strictly, this assumption cannot always be maintained, with the result that the vertical flux is not constant with height:

$\frac{\partial F_{z}}{\partial z}=-\frac{\partial \chi_{a}}{\partial t}-\frac{\partial F_{x}}{\partial x}+Q_{\text {chem }}$

In the case of ammonia, where exchange fluxes are relatively large in proportion to concentration, the flux divergence due to storage $\left(\partial \chi_{a} / \partial \mathrm{t}\right)$ can generally be ignored as trivial (Sutton et al., 1993a). However, the resulting difference in the vertical flux due to storage (the storage error, $\Delta F_{z, \text { sto }}$ ) may be found from:

$\Delta F_{z, \text { sto }}=\int_{0}^{z-d} \frac{\partial \chi_{a}}{\partial t} d z$ which is approximately equal to:

$\Delta F_{z, \text { sto }}=(z-d) \frac{\partial \chi_{a}}{\partial t}$

The horizontal flux divergence $\partial F_{x} / \partial x$ may be more significant for $\mathrm{NH}_{3}$, particularly where large $\mathrm{NH}_{3}$ sources exist in the vicinity, causing large local horizontal concentration gradients in the direction of the wind $\left(\partial \chi_{a} / \partial x\right)$ (Loubet et al., 2001, 2006; Milford et al., 2001a). Estimates of the difference in the vertical flux due to advection (the advection error, $\left.\Delta F_{z, \text { adv }}\right)$ are usually not made, due to lack of information on $\partial \chi_{a} / \partial x$. This issue was, however, given special attention in the Braunschweig Experiment, with both measurements and modelling of $\partial \chi_{a} / \partial x$ being conducted (Loubet et al., 2009). On this basis, where relevant, derived $\Delta F_{z, \text { adv }}$ were applied to correct the measured fluxes at $1 \mathrm{~m}\left(F_{z}(1 \mathrm{~m})\right)$ and provide estimates of the fluxes at the canopy surface $\left(F_{z}\left(z_{o}\right)\right)$.

Chemical production or consumption $\left(Q_{\text {chem }}\right)$ may also be significant for ammonia where either evaporation of ammonium containing aerosol, or production of aerosol, respectively, occur in the surface layer. The difference in the vertical flux due to these effects $\left(\Delta F_{z, \text { che }}\right)$ is assessed separately by Nemitz et al., 2009a.

\subsection{Ammonia measurement techniques and implemen- tation}

Ammonia concentrations were determined in gradient configuration at four locations using two different measurement techniques. At three out of the four sites the continuous flow wet denuder system "AMANDA" (Ammonia Measurement by ANnular Denuder sampling with online Analysis) was deployed (Wyers et al., 1993). This technique captures gaseous ammonia in a continuous-flow horizontal annular denuder using a stripping solution of $3.6 \mathrm{mM}$ sodium hydrogen sulphate $\left(\mathrm{NaHSO}_{4}\right)$ and determines the aqueous ammonium concentration online by conductivity analysis. The time resolution of this method can be set to $1 \mathrm{~min}$, however, in this instance, concentrations were measured sequentially for $150 \mathrm{~s}$ at each of three heights (including liquid-flow delay loops), resulting in a full profile measurement every $450 \mathrm{~s}$. These concentrations were averaged to 15 min periods for flux calculation. The air-flow rate of the AMANDAs was approximately $251 \mathrm{~min}^{-1}$ and the liquid flow rate through the denuders was approximately $1 \mathrm{ml} \mathrm{min}^{-1}$; the detection limit was about $0.02 \mu \mathrm{g} \mathrm{NH}_{3} \mathrm{~m}^{-3}$. The heights of the concentration measurements were varied throughout the measurement campaign according to the canopy height, but the maximum height and minimum heights above ground were $2.37 \mathrm{~m}$ and $0.32 \mathrm{~m}$ respectively. The three AMANDA systems were maintained by the Centre for Ecology and Hydrology (CEH) (UK), the German Federal Agricultural Research Institute (FAL-D) and the Hungarian Forest Research Institute (FRI), the last being in collaboration with the Hungarian Institute of Atmospheric Physics (IAP). 
Table 1. Summary of the different continuous ammonia concentration profile sampling systems used to calculate ammonia fluxes in the present study.

\begin{tabular}{llc}
\hline System acronym & System description & Location \\
\hline FRI & $\begin{array}{l}\text { AMANDA (3 point profile) operated by the Hungarian Forest Research Institute (FRI) } \\
\text { in collaboration with the Hungarian Institute of Atmospheric Physics (IAP). }\end{array}$ & Site 1 \\
FAL-CH & $\begin{array}{l}\text { Mini-WEDD (3 point profile) operated by the former Swiss Federal Research Station for } \\
\text { Agroecology and Agriculture (FAL-CH). }\end{array}$ & Site 1 \\
FAL-D & $\begin{array}{l}\text { AMANDA (3 point profile) operated by the German Federal } \\
\text { Agricultural Research Institute (FAL-D) }\end{array}$ \\
CEH & AMANDA (3 point profile) operated by the Centre for Ecology and Hydrology (CEH) UK. & Site 2 \\
\hline
\end{tabular}

A second continuous ammonia measurement technique utilised miniaturised Wet Effluent Denuders (mini-WEDD), which are silica-coated glass tubes (length $125 \mathrm{~mm}$ ) positioned vertically, with continuous flow of a stripping solution in a membrane tube analysed online by a four-channel fluorescent analyser (e.g. Neftel et al., 1998; Vecera and Dasgupta, 1991). The mini-WEDDs were maintained by ART the former Swiss Federal Research Station for Agroecology and Agriculture (FAL-CH) and placed at four heights ( $0.15 \mathrm{~m}, 0.3 \mathrm{~m}, 0.6 \mathrm{~m}$ and $1.2 \mathrm{~m}$ above ground). However, the lowest mini-WEDD concentration was not used in the flux calculations as it was judged to be too close to the canopy. An air-flow rate of $600 \mathrm{ml} \mathrm{min}^{-1}$ and a liquid flow rate of $0.12 \mathrm{ml} \mathrm{min}^{-1}$ were used. The detection limit was $0.1 \mu \mathrm{g}$ $\mathrm{NH}_{3} \mathrm{~m}^{-3}$. Calibration of both systems was conducted with aqueous standards of 0,50 and $500 \mu \mathrm{g} \mathrm{kg}^{-1} \mathrm{NH}_{4}^{+}$. A summary of the different $\mathrm{NH}_{3}$ measurement systems applied and acronyms used in the intercomparison is provided in Table 1.

During the experiment, aqueous calibration standards were prepared centrally and distributed amongst the ammonia analyser operators. In addition, unknown quality control standards were distributed on 3 occasions to test the accuracy of the analysers. On each occasion, 2 unknown standards were distributed and the difference in concentration measured by each analyser was compared with the actual concentration difference.

\subsection{Field site and instrument locations}

A full site description and diagram are given in Sutton et al. (2009b). The field site was intensively managed grassland of approximately 12 ha and the principal micrometeorological measurement location (Site 1) was $380 \mathrm{~m}$ from the western edge of the field, this being the main wind direction during the experiment. There was a second micrometeorological measurement location (Site 2), which was 210 m east of Site 1 and $36 \mathrm{~m}$ from the eastern edge of the field. Measurements were made at Site 2 in order that any advection of $\mathrm{NH}_{3}$ emitted from a farm located $610 \mathrm{~m}$ west of Site 1 (Hensen et al., 2009) could be identified and quantified (see Sect. 2.5). Two gradient AMANDAs (each consisting of 3 denuder inlets linked to a common ammonium detector) were deployed at Site 1 (FAL-D, FRI), as well as the mini-WEDD system (FAL-CH), while one gradient AMANDA (CEH) was deployed at Site 2. The field was cut for silage on the morning of 29 May 2000 (starting at 06:00 GMT), with grass removed from the field on the morning of 31 May 2000. The field was fertilized with $108 \mathrm{~kg} \mathrm{Nha}^{-1}$ calcium ammonium nitrate on the morning of 5 June 2000 (06:00-07:00 GMT).

\subsection{Data processing procedures}

The complexities of data processing are increased by the availability of the 4 independent estimates of $\mathrm{NH}_{3}$ concentration profiles. The following procedure was applied:

i) Any periods of calibration or obvious malfunctioning of each instrument were removed from the dataset of measured concentrations.

ii) Fluxes $F_{z}(1 \mathrm{~m})$ of $\mathrm{NH}_{3}$ and concentrations at $1 \mathrm{~m}$ $(\chi(1 \mathrm{~m}))$ were calculated according to Sect. 2.1. Flux measurements were rejected during periods when the fetch was obstructed by other equipment or by the edge of the field (see below for details).

iii) Once $F_{z}(1 \mathrm{~m})$ and $\chi(1 \mathrm{~m})$ estimates were available for the different systems, these were compared to identify any further periods where one system had malfunctioned or underperformed which had not yet been identified. These data were then removed.

iv) Given the different estimates of the 4 systems, gaps in the data create an artificial change in the mean estimate when one system goes offline or comes back online. To avoid this artefact, gaps of $<6 \mathrm{~h}$ in each instrument were filled for $F_{z}(1 \mathrm{~m})$ and $\chi(1 \mathrm{~m})$ according to the technique described below.

v) As the flux measurements were made at two sites, different vertical flux divergence will apply due to horizontal advection where local sources are present. The advection corrections for $1 \mathrm{~m}$ above $d$ were calculated by 
Table 2. Results of processing procedures for the ammonia flux data, from 21 May 2000, 10:00 GMT-15 June 2000, 12:00 GMT.

\begin{tabular}{|c|c|c|c|c|c|c|c|c|c|c|}
\hline \multirow{2}{*}{$\begin{array}{l}\text { Proceedure } \\
\text { Instrument }\end{array}$} & \multicolumn{5}{|c|}{ No. of valid (15-min) $F_{z}$ data points remaining } & \multicolumn{5}{|c|}{ Data coverage $(\%)$} \\
\hline & $\mathrm{CEH}$ & FRI & FAL-D & $\begin{array}{l}\text { FAL- } \\
\mathrm{CH}^{\mathrm{a}}\end{array}$ & $\begin{array}{l}\text { Mean } \\
\text { estimate }\end{array}$ & $\mathrm{CEH}^{\mathrm{b}}$ & $\mathrm{FRI}^{\mathrm{b}}$ & FAL-D ${ }^{b}$ & $\begin{array}{l}\text { FAL- } \\
\mathrm{CH}^{\mathrm{c}}\end{array}$ & $\begin{array}{l}\text { Mean } \\
\text { estimate }\end{array}$ \\
\hline Field Site number & 2 & 1 & 1 & 1 & & 2 & 1 & 1 & 1 & \\
\hline $\begin{array}{l}\text { i) Periods of calibration or ob- } \\
\text { vious malfunctioning of the } \\
\text { instruments removed. }\end{array}$ & 1912 & 1510 & 1893 & 1037 & & 79 & 63 & 79 & 69 & \\
\hline $\begin{array}{l}\text { ii) Measurements } \\
\text { obstructed wind } \\
\text { removed }\end{array}$ & 1400 & 1451 & 1841 & 1012 & & 58 & 60 & 76 & 68 & \\
\hline iii) gap-filling & & & & & & & & & & \\
\hline $\begin{array}{l}\text { No. of valid data points re- } \\
\text { maining after gapfilling }\end{array}$ & 1496 & 1531 & 1968 & 1372 & & 62 & 64 & 82 & 92 & \\
\hline Number of gaps filled & 23 & 13 & 31 & 71 & & & & & & \\
\hline Median gap length (mins) & 90 & 30 & 15 & 30 & & & & & & \\
\hline Std. dev. of gap length (mins) & 67 & 107 & 87 & 83 & & & & & & \\
\hline $\begin{array}{l}\text { iv) Mean gradient estimate, } \\
\text { all data }\end{array}$ & - & - & - & - & 2350 & - & - & - & - & 97.5 \\
\hline $\begin{array}{l}\text { v) Data passing micromet cri- } \\
\text { teria }\end{array}$ & - & - & - & - & 1652 & - & - & - & - & 68.5 \\
\hline
\end{tabular}

a FAL-CH gradient data commences on 30 May 2000, 22:15 GMT, up until 30 May the system measured within-canopy profiles.

b $\%$ data coverage calculated for period 21 May 2000, 10:00 GMT-15 June 2000, 12:00 GMT.

c $\%$ data coverage calculated for period 30 May 2000, 22:15 GMT-15 June 2000, 12:00 GMT.

Loubet et al. (2009) for the Site 1 and 2 measurements and applied to the measured fluxes, resulting in an estimate of the fluxes at the canopy surface $\left(F_{z}\left(z_{o}\right)\right)$ (see Sect. 3.3). No corrections to the data for the potential effect of chemical production or consumption are made here, as this effect is assessed by Nemitz et al. (2009a).

vi) The "mean gradient estimate" (subscript $\mathrm{mg}$ ) was calculated for $\left(F_{z}\left(z_{o}\right)\right)$ and $\chi(1 \mathrm{~m})$, as the arithmetic mean of all the remaining individual measurements. At the same stage, corrections for storage errors were also applied.

vii) The data were filtered according to the passing or failing of a set of defined micrometeorological criteria (see below). Data failing these criteria were retained in the dataset, but distinguished as being of lower reliability.

There was a substantial amount of measurement equipment at Site 1, concentrated on a N-S axis, as well as three mobile laboratories in the $\mathrm{N}$ direction (see site description in Sutton et al., 2009b). As a result, flux measurements from the FAL-D and FRI gradient systems were rejected for wind directions from both the $\mathrm{N}$ and $\mathrm{S}$ direction $\left(0^{\circ}\right.$ to $20^{\circ}$ and $180^{\circ}$ to $190^{\circ}$ rejected), whilst flux measurements were rejected for winds from the NNE direction $\left(10^{\circ}\right.$ to $\left.45^{\circ}\right)$ for the FAL-CH gradient system. Due to the close proximity of the edge of the field to the east of Site 2, flux measurements were rejected at this site for wind direction $0^{\circ}$ to $170^{\circ}$.

The gapfilling technique applied for each instrument involved calculating the ratio of the individual flux measurement to the mean estimate at the start and the end of the gap and then interpolating this ratio. This interpolated ratio was then multiplied by the available mean estimate to fill in missing data. This method propagates the deviations from the mean present at the start and end of the gap, and limits the occurrence of step changes in the flux when individual analysers fail or are restored in the dataset. Only gaps of $<6 \mathrm{~h}$ were filled.

Finally, the data were filtered according to micrometeorological criteria to identify periods where the fluxes are estimated with less certainty. These micrometeorological criteria were: $u(1 \mathrm{~m})<0.8 \mathrm{~m} \mathrm{~s}^{-1},|L|<5 \mathrm{~m}$ and cumulative normalised footprint function $(\mathrm{CNF})<67 \%$. The cumulative normalised footprint function was calculated using the Kormann and Meixner (2001) formulation as described in $\mathrm{Ne}$ mitz et al. (2009b).

\section{Results}

\subsection{Data processing}

The data processing procedures ensured that high data coverage at individual sites was achieved even after periods of malfunctioning and obstructed wind sectors were removed (Table 2). Having four estimates of the flux lead to a "mean gradient estimate" of the flux with an overall data coverage of $98 \%$. This highlights the advantage of having a number of independent systems to achieve a robust estimate of the flux. The data coverage was reduced to $69 \%$ if the fluxes which were calculated with less certainty were removed, showing that meteorological conditions (low 
Table 3. Results of the blind testing of aqueous ammonium Quality Control standards. The blind standards were prepared by a separate laboratory (ECN, Netherlands). On each occasion two standards were distributed and the difference in concentration measured by each analyser was compared with the actual concentration difference to give an indication of the performance across the full measurement range. The $\%$ difference shown was calculated as $\left(100-\left(100 \Delta\left[\mathrm{NH}_{4}^{+}\right]_{\mathrm{lab}} / \Delta\left[\mathrm{NH}_{4}^{+}\right]_{\mathrm{QCstd}}\right)\right)$.

\begin{tabular}{cllllll}
\hline Date of test & $\begin{array}{l}{\left[\mathrm{NH}_{4}^{+}\right]_{a q} \text { of }} \\
\text { QC standard 1 }\left(\mu \mathrm{gl}^{-1}\right)\end{array}$ & $\begin{array}{l}{\left[\mathrm{NH}_{4}^{+}\right]_{a q} \text { of }} \\
\text { QC standard 2 }\left(\mu \mathrm{gl}^{-1}\right)\end{array}$ & \multicolumn{3}{c}{$\begin{array}{l}\text { \% difference in concentration compared } \\
\text { with the unknown standards FRI FAL-D FAL-CH CEH }\end{array}$} \\
\hline 25 May 2000 & 22 & 84 & $44^{*}$ & 13 & 21 & 16 \\
31 May 2000 & 16 & 98 & 16 & 41 & $\mathrm{n} / \mathrm{a}$ & 10 \\
6 June 2000 & 273 & 38 & 4 & 21 & $\mathrm{n} / \mathrm{a}$ & -3 \\
\hline
\end{tabular}

* This test was conducted on 22 May 2000 for FRI and a contaminated stripping solution container was found to be the cause; $\mathrm{n} / \mathrm{a}$ : not available.

windspeed, stable conditions) were the main limitation to obtaining a complete flux dataset. Data on the gapfilling procedure revealed that FAL-CH had the greatest number of gaps filled and that the median gap length varied from $15 \mathrm{~min}$ (FAL-D) to $90 \mathrm{~min}(\mathrm{CEH})$.

\subsection{Temporal inter-comparison of gradient measure- ments}

The range of $\mathrm{NH}_{3}$ concentrations at $1 \mathrm{~m}$ and fluxes from the 4 different systems are shown for example days from the precutting, post-cutting and post-fertilizing periods (Figs. 1 and $2)$. These figures show that there were periods of close agreement (e.g. 6 and 7 June 2000) and periods of substantial divergence (e.g. 8 June 2000). It can be seen that for certain periods (31 May to 2 June 2000) there were consistent concentration differences between the different instruments with FAL-D generally reading higher concentrations than $\mathrm{CEH}$ and FAL-CH.

The blind testing of the aqueous ammonium Quality Control standards by the different analysers did indicate periods of significant concentration differences (Table 3). In particular, the result of FAL-D over-reading by $41 \%$ on 31 May 2000 is consistent with Fig. 1b. However, the small number of aqueous quality tests meant that it was not possible to adjust the concentrations in an objective manner and so the quality tests were used for interpretation rather than adjustment.

The flux intercomparison highlights the changing pattern of $\mathrm{NH}_{3}$ exchange during the experiment; before the cutting of the grass the flux was predominantly deposition to the surface. After cutting of the grass, the $\mathrm{NH}_{3}$ exchange changed to predominantly emission with emission fluxes of up to $760 \mathrm{ng} \mathrm{m}^{-2} \mathrm{~s}^{-1}$, whilst after fertilization the fluxes according to individual analyzers increased up to $6000 \mathrm{ng} \mathrm{m}^{-2} \mathrm{~s}^{-1}$. The emission fluxes peaked in the daytime and were generally close to zero during nighttime. As with the comparison of ammonia air concentrations, there were periods of close agreement (e.g. 6 and 7 June 2000) and periods of substantial disagreement (e.g. 1 and 8 June 2000). However, gen-
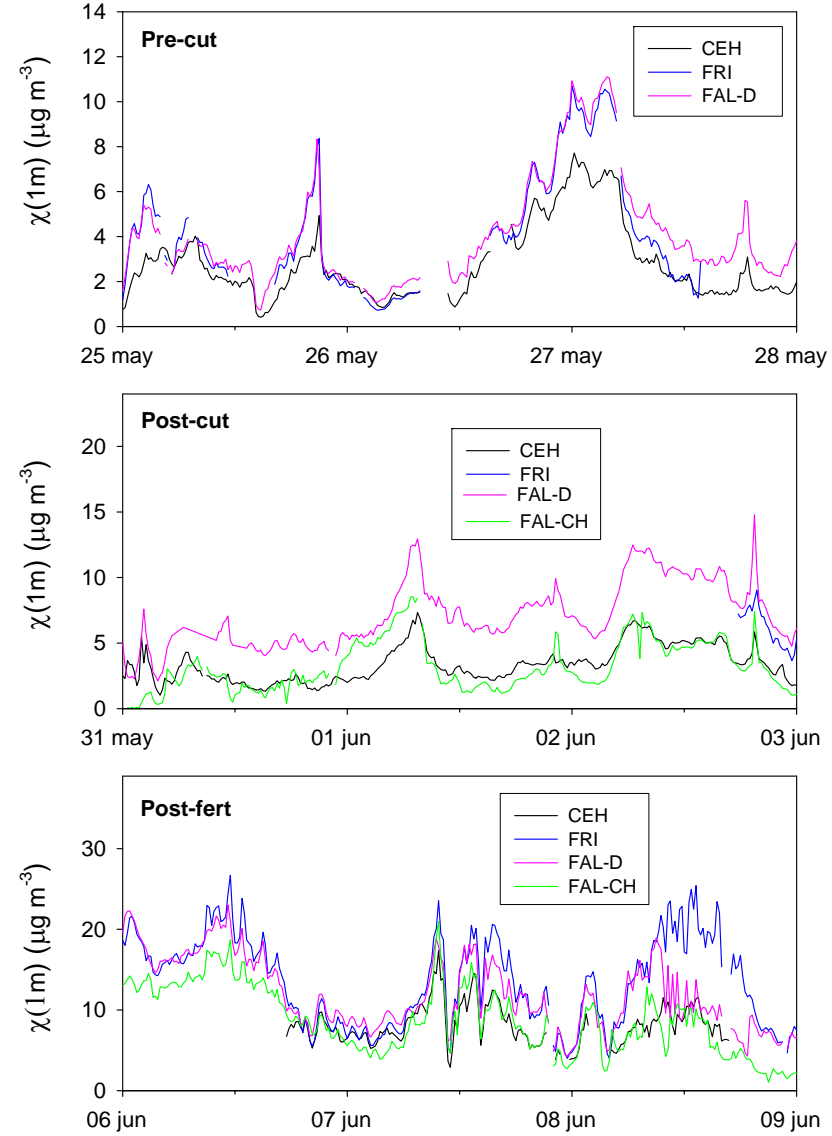

Fig. 1. Examples of $\chi(1 \mathrm{~m})$ for $\mathrm{NH}_{3}$ from the four different systems for pre-cutting, post-cutting and post-fertilizing periods. Centre for Ecology and Hydrology (CEH), Hungarian Forest Research Institute (FRI), German Federal Agricultural Research Institute (FALD) and Swiss Federal Research Station for Agroecology and Agriculture (FAL-CH). FAL-CH gradient data comences on 30 May 2000. Tick labels mark 00:00 GMT.

erally the fluxes from the different systems showed a similar structure and response to the management activities on the field. The larger flux values (e.g. FAL-D on 1 and 2 June 

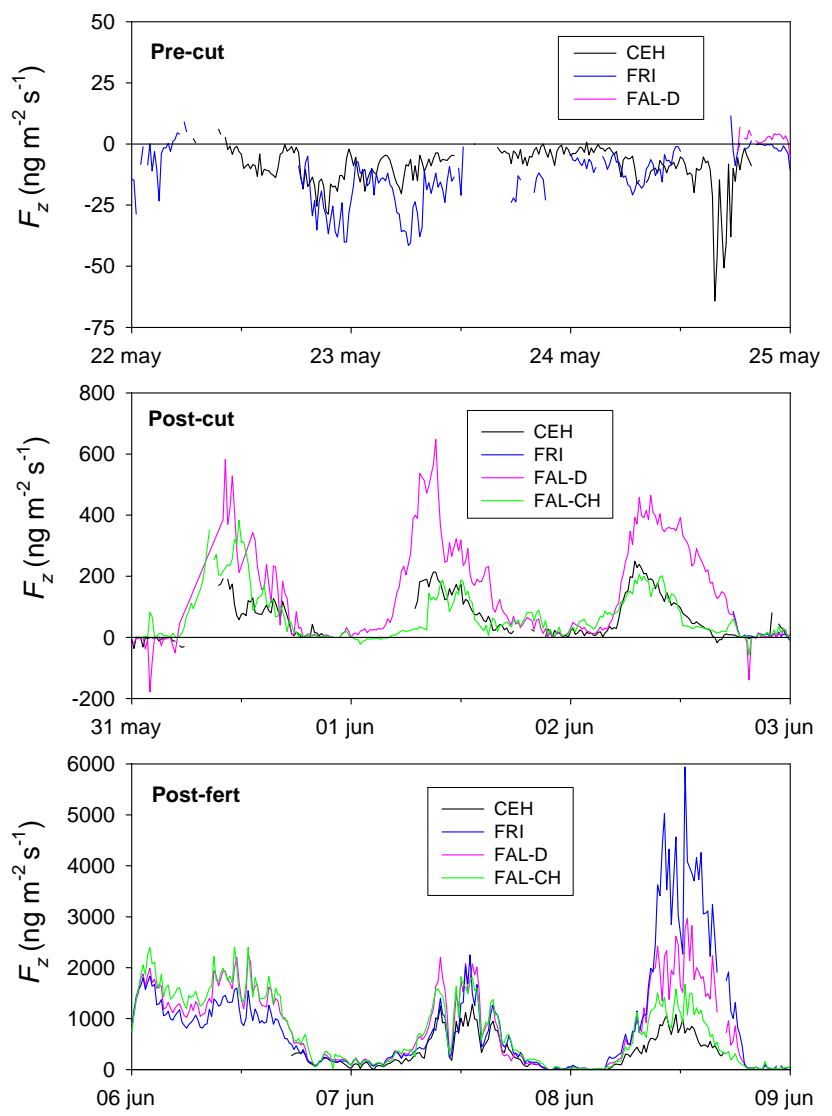

Fig. 2. Example of $\mathrm{NH}_{3}$ fluxes $\left(F_{z}\right)$ from the 4 different systems for pre-cutting, post-cutting and post-fertilizing periods. Centre for Ecology and Hydrology (CEH), Hungarian Forest Research Institute (FRI), German Federal Agricultural Research Institute (FALD) and Swiss Federal Research Station for Agroecology and Agriculture (FAL-CH). FAL-CH gradient data comences on 30 May 2000. Tick labels mark 00:00 GMT.

2000) were generally coupled with larger concentrations at $1 \mathrm{~m}$, although this was not always the case (e.g. FAL-D and FRI in the early hours of 8 June 2000). Scatter plots comparing the $\mathrm{NH}_{3}$ concentration and flux for the different systems are presented in Sect. 3.4.

\subsection{Assessment of advection corrections}

Estimates of the difference in the vertical flux due to advection (the advection error, $\Delta F_{z, \text { adv }}$ ) were derived from both measurements and modelling by Loubet et al. (2009). The modelled estimates of $\Delta F_{z}$,adv were applied to correct the flux measurements $\left(F_{z}(1 \mathrm{~m})\right)$ in order to provide an estimate of the fluxes at the canopy surface $\left(F_{z}\left(z_{o}\right)\right)$. Examples of the magnitude of the advection errors in relation to the flux measurements for particular periods are given in Loubet et al. (2009). The modelled advection errors during the pre-cut period due to the farm $610 \mathrm{~m}$ from Site 1 estimated by Loubet et al. (2009), ranged between 0 to $27 \mathrm{ng} \mathrm{m}^{-2} \mathrm{~s}^{-1}$. However,
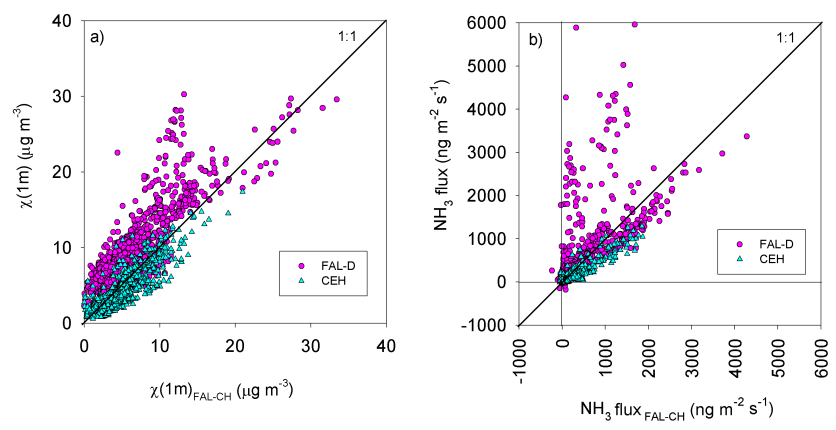

Fig. 3. Comparison of (a) $\chi(1 \mathrm{~m})$ and (b) $\mathrm{NH}_{3}$ flux at $z_{o}$ (corrected for advection) measurements. German Federal Agricultural Research Institute (FAL-D), Centre for Ecology and Hydrology (CEH) and Swiss Federal Research Station for Agroecology and Agriculture (FAL-CH).

relatively few periods of advection from the farm were observed due to winds occurring directly from the $\mathrm{W}$ occurring for only a small period of the time, and accounted on average for $32 \%$ of the measured flux. As well as advection due to the farm emissions, advection errors also occurred due to $\mathrm{NH}_{3}$ emissions from the field itself, which were largest following fertilization of the field. Although these were larger in absolute terms ( -209 to $13 \mathrm{ng} \mathrm{m}^{-2} \mathrm{~s}^{-1}$ ), they represented a smaller percentage of the measured fluxes at 1 to $2 \%$. For the week following 29 May 2000 (post-cut period), the farm and field advection errors amounted on average to $+3 \%$ and $-4 \%$ of the measured fluxes, respectively (Loubet et al., 2009).

\subsection{Inter-comparison of gradient measurements}

\subsubsection{Comparisons of $\chi(1 \mathrm{~m})$ and $\mathbf{F}_{z}\left(\mathbf{z}_{o}\right)$ against FAL- CH}

FAL-CH was chosen as the reference for a preliminary analysis because it was present at Site 1 and also because it helps to illustrate the variation in the response of the FALD analyzer. Comparisons of $\chi(1 \mathrm{~m})$ and $F_{z}\left(z_{o}\right)$ for each instrument versus FAL-CH were conducted (FAL-CH data not available for the pre-cutting period). FAL-D, $\chi(1 \mathrm{~m})$ and $F_{z}\left(z_{o}\right)$ agreed well with FAL-CH across the data range for some of the time (Fig. 3). However, there were a considerable number of data points which greatly overestimated the concentration and flux compared with FAL-CH. The fact that this was not evident for the whole period suggests that there was some variation in the accuracy of the FAL-D analyser throughout the measurement period. For example, this could be due to variation in the accuracy of the calibration. Inaccuracies in the measurement could be exacerbated in the large concentration range, where the calibration is no longer as robust. In addition, temperatures inside the analysers reached $40^{\circ} \mathrm{C}$ on some days. Although the concentration measurements were corrected for temperature, inaccuracies in the temperature correction could lead to overestimation 
Table 4. Summary of regression results of $\chi(1 \mathrm{~m})$ of the individual systems versus the value for the mean gradient $(\chi(1 \mathrm{~m}) \mathrm{mg})$ expressed in $\mu \mathrm{g} \mathrm{m}^{-3}$. The regression is given first as a simple linear function (as shown in Fig. 4): $\chi(1 \mathrm{~m})_{\text {individ }}=c \chi(1 \mathrm{~m})_{\mathrm{mg}}+b$ and secondly as $\log _{10}\left[\chi(1 \mathrm{~m})_{\text {individ }}\right]=e \log _{10}\left[\chi(1 \mathrm{~m})_{\mathrm{mg}}\right]+d$. Data from $3,8,9$ and 10 June are excluded.

\begin{tabular}{|c|c|c|c|c|c|c|}
\hline Linear results & c (slope) & c $95 \%$ confidence limits & $\mathrm{b}$ (intercept) & b 95\% confidence limits & $\mathrm{n}$ & $r^{2}$ \\
\hline$\chi(1 \mathrm{~m})_{\mathrm{FAL}-\mathrm{D}}$ & 0.99 & {$[0.98,1.01]$} & 1.28 & {$[1.19,1.37]$} & 1525 & 0.94 \\
\hline$\chi(1 \mathrm{~m})_{\mathrm{CEH}}$ & 0.82 & {$[0.81,0.83]$} & -0.21 & {$[-0.27,-0.15]$} & 1256 & 0.93 \\
\hline$\chi(1 \mathrm{~m})_{\mathrm{FRI}}$ & 1.15 & {$[1.13,1.17]$} & -0.70 & {$[-0.81,-0.59]$} & 1097 & 0.95 \\
\hline$\chi(1 \mathrm{~m})_{\mathrm{FAL}-\mathrm{CH}}$ & 0.92 & {$[0.91,0.94]$} & -0.32 & {$[-0.44,-0.20]$} & 990 & 0.94 \\
\hline Log Transformed results & e (slope) & e $95 \%$ confidence limits & $\mathrm{d}$ (intercept) & d $95 \%$ confidence limits & $n$ & $r^{2}$ \\
\hline$\chi(1 \mathrm{~m})_{\mathrm{FAL}-\mathrm{D}}$ & 0.89 & {$[0.88,0.90]$} & 0.18 & {$[0.17,0.19]$} & 1525 & 0.93 \\
\hline$\chi(1 \mathrm{~m})_{\mathrm{CEH}}$ & 0.98 & {$[0.96,1.00]$} & -0.12 & {$[-0.13,-0.10]$} & 1256 & 0.86 \\
\hline$\chi(1 \mathrm{~m})_{\mathrm{FRI}}$ & 1.25 & {$[1.22,1.28]$} & -0.20 & {$[-0.22,-0.18]$} & 1097 & 0.86 \\
\hline$\chi(1 \mathrm{~m})_{\mathrm{FAL}-\mathrm{CH}}$ & 1.15 & {$[1.11,1.19]$} & -0.20 & {$[-0.23,-0.17]$} & 990 & 0.75 \\
\hline
\end{tabular}
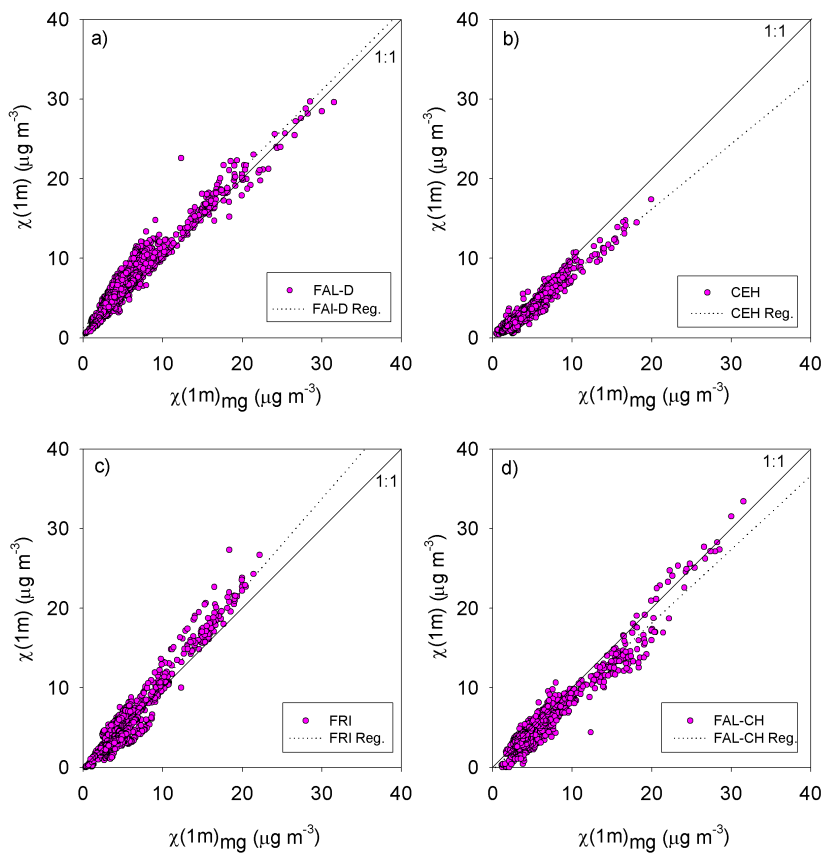

Fig. 4. Regression of $\chi(1 \mathrm{~m})$ from each system against mean gradient concentration, $\chi(1 \mathrm{~m})_{\mathrm{mg}}$, for (a) German Federal Agricultural Research Institute (FAL-D), (b) Centre for Ecology and Hydrology (CEH), (c) Hungarian Forest Research Institute (FRI) and (d) Swiss Federal Research Station for Agroecology and Agriculture (FAL$\mathrm{CH})$. Data from 3, 8, 9 and 10 June 2000 are not included.

of concentrations. A similar effect was seen in some periods for the FRI AMANDA data of $\chi(1 \mathrm{~m})$ and $F_{z}\left(z_{o}\right)$ (data not shown). CEH AMANDA $\chi(1 \mathrm{~m})$ and $F_{z}\left(z_{o}\right)$, underestimated the FAL-CH mini-WEDD values, but did not show the variation in agreement demonstrated by FAL-D and FRI.

\subsubsection{Regressions of $\chi(1 \mathrm{~m})$ and $F_{z}\left(z_{o}\right)$ against mean gradient estimate}

After the data processing procedures were conducted as detailed in Sect. 2.4 the "mean gradient estimate" was calculated for $F_{z}\left(z_{o}\right)$ and $\chi(1 \mathrm{~m})\left(F_{z}\left(z_{o}\right)_{\mathrm{mg}}\right.$ and $\left.\chi(1 \mathrm{~m})_{\mathrm{mg}}\right)$, this is the arithmetic mean of all available individual measurements remaining in the dataset. These data include the corrections for advection. A comparison of $\chi(1 \mathrm{~m})_{\mathrm{mg}}$ versus the individual systems was conducted (Fig. $4 \mathrm{a}-\mathrm{d}$ ). The regression results are presented in Table 4, these include results calculated from the simple linear function and also using log transformed data.

Data from 3, 8, 9 and 10 June 2000 were not included in the regression because on these days there was significant disagreement between the systems with FAL-D and FRI giving higher estimates compared with the CEH and FAL$\mathrm{CH}$ estimates. To include the FAL-D and FRI estimates for these days in the regression would bias the regression towards FAL-D and FRI and might give a false impression of the overall dataset.

With data from 3, 8, 9 and 10 June removed, Fig. 4a-d demonstrate that there was close agreement of $\chi(1 \mathrm{~m})$ between each individual system and the mean estimate across the full concentration range. As indicated by the temporal graphs, FAL-D and FRI showed slightly higher concentrations than the best estimate, whilst FAL-CH and $\mathrm{CEH}$ showed slightly lower. The $r^{2}$ value for all the linear regressions was high $(>0.93)$ (Table 4$)$ which gives confidence in the 4 systems and the values of $\chi(1 \mathrm{~m})_{\mathrm{mg}}$.

The regression results for the log transformed data show lower values of $r^{2}$ with respect to the linear results. This is due to increased scatter of small concentrations near the detection limit in the $\log$ transformed dataset, resulting in a greater variance in the dataset for low concentrations. By contrast, in the simple linear plot (Fig. 4) the variance in y is 

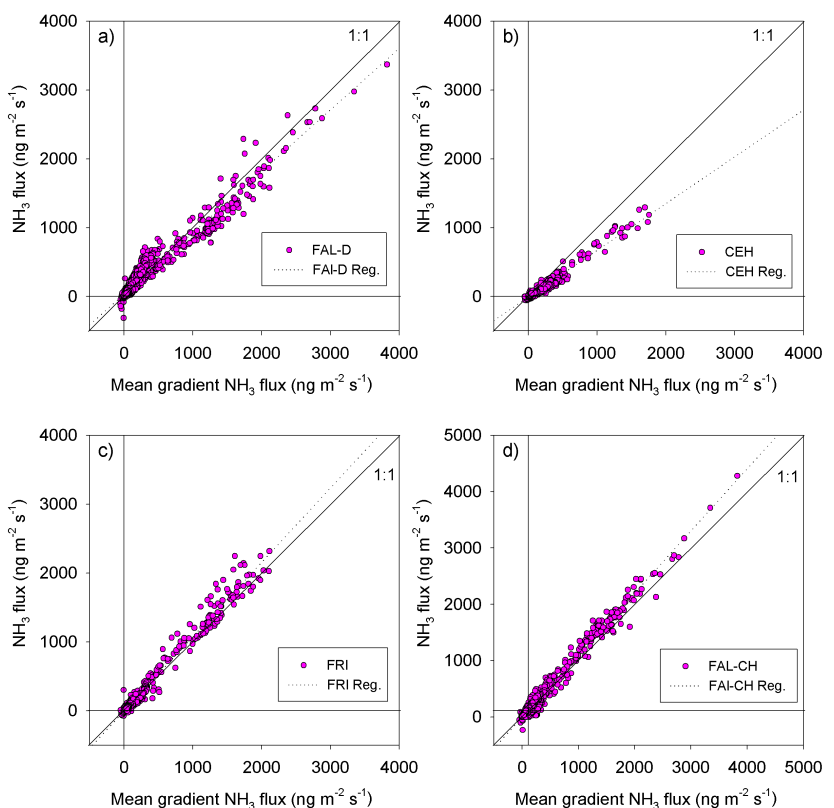

Fig. 5. Regression of $\mathrm{NH}_{3}$ flux from each system against mean gradient flux for (a) German Federal Agricultural Research Institute (FAL-D), (b) Centre for Ecology and Hydrology (CEH), (c) Hungarian Forest Research Institute (FRI) and (d) Swiss Federal Research Station for Agroecology and Agriculture (FAL-CH). Data from 3, 8, 9 and 10 June 2000 are not included.

similar for the full range of concentrations, and therefore this is more appropriate for the comparison of the data than the $\log$ transformed data.

Such a log transformation for the fluxes data is less suited, due to the existence of negative fluxes. The most negative flux, recorded for FAL-D was $-315 \mathrm{ng} \mathrm{m}^{-2} \mathrm{~s}^{-1}$ and a transformation of $\left(\log _{10}\left[F_{z}\left(z_{o}\right)_{\text {individ }}+320\right]=e \log _{10}\left[F_{z}\right.\right.$ $\left.\left.\left(z_{o}\right)_{\mathrm{mg}}+320\right]+d\right)$ was tested. However, this did not succeed in normalizing the data, while the variance was again larger at smaller values (due to scatter at smaller fluxes). For this reason, only the linear relationships are shown for the fluxes.

The regression of $F_{z}\left(z_{o}\right)_{\mathrm{mg}}$ versus $F_{z}\left(z_{o}\right)$ from the individual systems (Fig. 5a-d, Table 5) demonstrates that once the four uncertain days $(3,8,9$ and 10 June) were removed from the regression then FAL-D tended to underestimate the flux compared with the mean gradient estimate, as did CEH. By contrast, FRI and FAl-CH both overestimated the mean gradient flux by about $10 \%$ compared with the mean gradient estimate.

As a result of the disagreement between systems on the $3,8,9$ and 10 June an "alternative gradient estimate" for $\chi$ $(1 \mathrm{~m})$ and $F_{z}\left(z_{o}\right)$ was proposed for these days. The alternative gradient estimate (subscript ag) consisted of the mean of the two systems (CEH and FAL-CH). It was not considered that there was sufficient justification to remove the high measurements from the mean dataset. However, it was suspected that on these days the two high systems might not have been
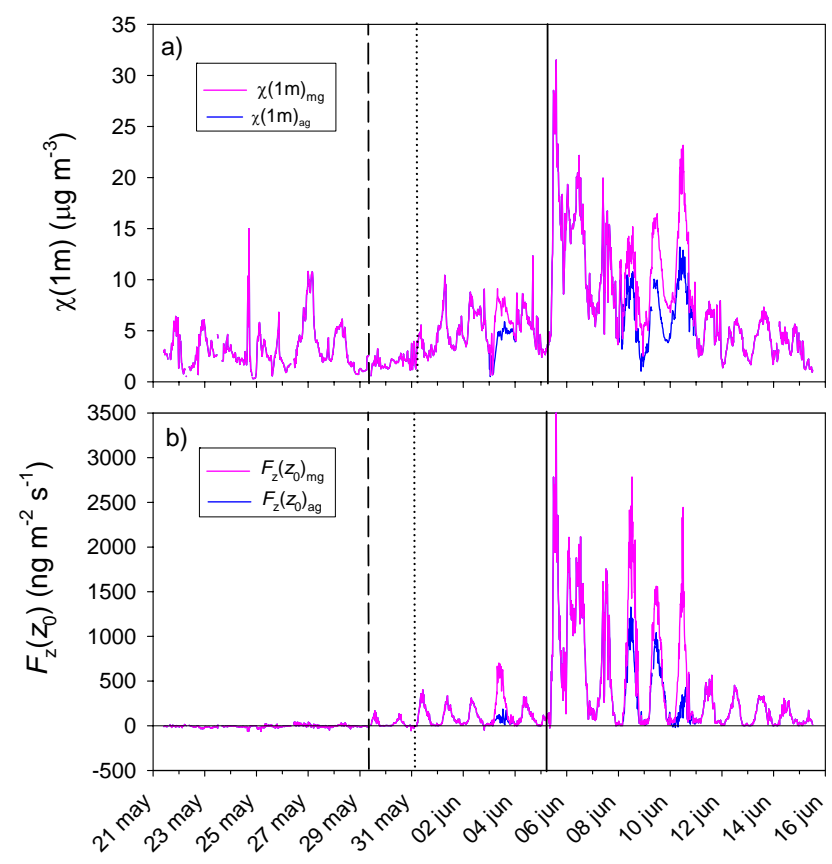

Fig. 6. Mean gradient estimate of (a) $\chi(1 \mathrm{~m})_{\mathrm{mg}}$ and (b) net $\mathrm{NH}_{3}$ flux $\left(F_{Z}\left(z_{o}\right)_{\mathrm{mg}}\right)$ showing response to management activities. The alternative gradient estimate is also shown $\left(\chi(1 \mathrm{~m})_{a g}\right.$ and $F_{z}\left(z_{o}\right)_{a g}$ on 3, 8, 9 and 10 June 2000, these are days with high instrument uncertainty (see text). Vertical lines indicate cutting (dashed line), removal of the grass from the field (dotted line) and $\mathrm{NH}_{4} \mathrm{NO}_{3}$ fertilization (solid line).

operating correctly. Therefore, this alternative estimate was also provided to other end-users of the data.

\section{5 $\mathrm{NH}_{3}$ concentration and flux in relation to manage- ment activities}

The resulting mean gradient concentrations of $\mathrm{NH}_{3}$ at $1 \mathrm{~m}$ $\left(\chi(1 \mathrm{~m})_{\mathrm{mg}}\right)$ and flux $\left(F_{z}\left(z_{o}\right)_{\mathrm{mg}}\right)$ for the whole period (Fig. 6) demonstrate clearly the effect of the management activities (cutting and fertilizing) on the concentration and flux. In addition to the mean gradient estimate, Fig. 6 also shows the alternative gradient estimate for $\chi(1 \mathrm{~m})$ and $F_{z}\left(z_{o}\right)$ on $3,8,9$ and 10 June. Statistics for the mean gradient estimate of $\chi(1 \mathrm{~m})$ and $F_{z}\left(z_{o}\right)$ were calculated for the three periods: i) pre-cutting; ii) post-cutting/pre-fertilizing and iii) post-fertilizing (Tables 6 and 7). These data have been corrected for both advection and storage errors.

The effect of the data filtering for micrometeorological restrictions (Sect. 2.4, step vii) is illustrated, with slightly larger $\chi(1 \mathrm{~m})$ and $F_{z}\left(z_{o}\right)$ from the filtered dataset. This reflects a bias in the filtered dataset, that more data were excluded from night-time conditions, when $\chi(1 \mathrm{~m})$ and $F_{z}\left(z_{o}\right)$ were smallest. 
Table 5. Summary of linear regression results of $F_{z}\left(z_{o}\right)$ of the individual systems versus $F_{z}\left(z_{o}\right)_{\mathrm{mg}}$ expressed in ng m ${ }^{-2} \mathrm{~s}^{1}$, given as $F_{z}\left(z_{o}\right)_{\text {individ }}=c F_{z}\left(z_{o}\right)_{\mathrm{mg}}+b$. The estimates are derived from the data shown in Fig. 5.

\begin{tabular}{lllllll}
\hline & $\mathrm{c}($ slope $)$ & $\mathrm{c} 95 \%$ confidence limits & $\mathrm{b}$ (intercept) & $\mathrm{b} 95 \%$ confidence limits & $n$ & $r^{2}$ \\
\hline$F_{z}\left(z_{o}\right)_{\mathrm{FAL}-\mathrm{D}}$ & 0.89 & {$[0.88,0.90]$} & 33.45 & {$[28.68,38.22]$} & 1525 & 0.95 \\
$F_{z}\left(z_{o}\right)_{\mathrm{CEH}}$ & 0.68 & {$[0.67,0.69]$} & -8.86 & {$[-10.75,-6.97]$} & 1256 & 0.96 \\
$F_{z}\left(z_{o}\right)_{\mathrm{FRI}}$ & 1.08 & {$[1.07,1.09]$} & -5.36 & {$[-9.16,-1.55]$} & 1097 & 0.98 \\
$F_{z}\left(z_{o}\right)_{\mathrm{FAL}-\mathrm{CH}}$ & 1.10 & {$[1.09,1.11]$} & -5.58 & {$[-11.16,0.00]$} & 990 & 0.98 \\
\hline
\end{tabular}

Table 6. Variations in $15 \mathrm{~min}$ measurements of $\mathrm{NH}_{3}$ concentration at $1 \mathrm{~m}$ from the mean gradient, $\chi(1 \mathrm{~m})_{\mathrm{mg}}$, throughout different measurement periods, before and after micromet filtering.

\begin{tabular}{|c|c|c|c|c|c|c|c|c|}
\hline Period & Dataset & $\begin{array}{l}\text { Mean } \\
\mu \mathrm{g} \mathrm{m}^{-3}\end{array}$ & $\begin{array}{l}\text { Stdev } \\
\mu \mathrm{g} \mathrm{m}^{-3}\end{array}$ & $\begin{array}{l}\text { Median } \\
\mu \mathrm{g} \mathrm{m}^{-3}\end{array}$ & $\begin{array}{l}\text { Min } \\
\mu \mathrm{g} \mathrm{m}^{-3}\end{array}$ & $\begin{array}{l}\operatorname{Max} \\
\mu \mathrm{g} \mathrm{m}^{-3}\end{array}$ & $n$ & $\begin{array}{l}\text { Data } \\
\text { Coverage }(\%)\end{array}$ \\
\hline Pre-cutting & All data & 3.22 & 2.06 & 2.64 & 0.29 & 15.00 & 705 & 93.6 \\
\hline Pre-cutting & After filtering & 3.25 & 2.03 & 2.64 & 0.35 & 10.81 & 592 & 78.6 \\
\hline $\begin{array}{l}\text { Post-cutting/ } \\
\text { Pre-fertilizing }\end{array}$ & All data & 4.32 & 2.15 & 3.96 & 0.58 & 12.32 & 675 & 98.7 \\
\hline $\begin{array}{l}\text { Post-cutting/ } \\
\text { Pre-fertilizing }\end{array}$ & After filtering & 4.50 & 2.46 & 3.86 & 0.58 & 12.32 & 393 & 57.5 \\
\hline Post-fertilizing & All data & 8.38 & 5.55 & 6.78 & 0.92 & 31.52 & 970 & 99.7 \\
\hline Post-fertilizing & After filtering & 9.21 & 5.76 & 7.38 & 0.92 & 31.52 & 667 & 68.6 \\
\hline
\end{tabular}

Pre-cutting: 21 May, 10:00 GMT-29 May, 06:00 GMT; Post-cutting/Pre-fertilizing: 29 May, 06:00 GMT-5 June, 06:00 GMT; Post fertilizing: 5 June, 06:00 GMT-15 June, 12:00 GMT

\subsubsection{Pre-cutting}

Prior to cutting of the grass, the flux was predominantly deposition to the surface (see Fig. 2 for typical diurnal course). The mean flux of the pre-cutting period was $-5.8 \mathrm{ng} \mathrm{m}^{-2} \mathrm{~s}^{-1}$ if all data were included and $-6.0 \mathrm{ng} \mathrm{m}^{-2} \mathrm{~s}^{-1}$ if only data which passed the micrometeorological criteria were included. Any emission which was observed was generally small, the maximum emission observed over the period was $42 \mathrm{ng} \mathrm{m}^{-2} \mathrm{~s}^{-1}$. The intensive grassland was generally acting as a sink for $\mathrm{NH}_{3}$ during this period.

\subsubsection{Post-cutting, pre-fertilizing}

Immediately after cutting (29 May 2000, 06:00 GMT) the $\mathrm{NH}_{3}$ flux switched to emission. The emission had a diurnal pattern with very small fluxes during night-time and emission fluxes increasing during the daytime; daily peak emission values were 135 to $700 \mathrm{ng} \mathrm{m}^{-2} \mathrm{~s}^{-1}$. The mean flux during the cutting period was $100 \mathrm{ng} \mathrm{m}^{-2} \mathrm{~s}^{-1}$ (all data) or $138 \mathrm{ng} \mathrm{m}^{-2} \mathrm{~s}^{-1}$ (only data which passes the micromet criteria). These values are equivalent to 71 and $98 \mathrm{~g} \mathrm{~N} \mathrm{ha}^{-1}$ day $^{-1}$, respectively.

\subsubsection{Post-fertilizing}

There was a rapid increase in $\mathrm{NH}_{3}$ flux observed following the fertilization with $\mathrm{N}$ (5 June 2000, 06:00 GMT), with values peaking at $3820 \mathrm{ng} \mathrm{m}^{-2} \mathrm{~s}^{-1}$. During the first two nights after fertilization ( 5 June and 6 June) there were mean nocturnal emissions of $1050 \mathrm{ng} \mathrm{m}^{-2} \mathrm{~s}^{-1}$ and $150 \mathrm{ng} \mathrm{m}^{-2} \mathrm{~s}^{-1}$, respectively. The mean flux over the whole post-fertilizing period was $474 \mathrm{ng} \mathrm{m}^{-2} \mathrm{~s}^{-1}$ (all data) or $559 \mathrm{ng} \mathrm{m}^{-2} \mathrm{~s}^{-1}$ (only data which passed the micrometeorological criteria). These values are equivalent to 337 and $398 \mathrm{~g} \mathrm{Nha}^{-1} \mathrm{day}^{-1}$, respectively. The emission flux decreased on 11 June 2000, but was still up to $565 \mathrm{ng} \mathrm{m}^{-2} \mathrm{~s}^{-1} 13$ days after cutting.

The accumulated flux was $-0.03,0.50$ and $3.41 \mathrm{~kg} \mathrm{~N} \mathrm{ha}^{-1}$ for the pre-cutting, post cutting and post fertilizing periods, respectively. This accumulated flux up to 10 days after the fertilization represented $3.2 \%$ of the $\mathrm{N}$ applied, or an equivalent of $3.6 \%$ if the post-cutting emissions were included.

\subsubsection{Inter-instrument differences for $\chi(1 \mathrm{~m})$ and $\mathbf{F}_{z}\left(\mathbf{z}_{o}\right)$ for main management periods}

It is relevant to consider the statistics of $\chi(1 \mathrm{~m})$ and $F_{z}\left(\mathrm{z}_{o}\right)$ between the different ammonia analyzers for the main management periods. With longer-averaging periods the uncertainties between the different systems decreased (Table 8). 
Table 7. Variations in 15 min measurements of mean gradient net $\mathrm{NH}_{3}$ flux $\left(F_{z}\left(z_{o}\right)_{\mathrm{mg}}\right)$ throughout different measurement periods, before and after micromet filtering.

\begin{tabular}{|c|c|c|c|c|c|c|c|c|}
\hline Period & Dataset & $\begin{array}{r}\text { Mean } \\
\mathrm{ng} \mathrm{m}^{-2} \mathrm{~s}^{-1}\end{array}$ & $\begin{array}{r}\text { Stdev } \\
\mathrm{ng} \mathrm{m}^{-2} \mathrm{~s}^{-1}\end{array}$ & $\begin{array}{r}\text { Median } \\
n g m^{-2} s^{-1}\end{array}$ & $\begin{array}{r}\text { Min } \\
\mathrm{ng} \mathrm{m}^{-2} \mathrm{~s}^{-1}\end{array}$ & $\begin{array}{c}\operatorname{Max} \\
\operatorname{ng~m}^{-2} \mathrm{~s}^{-1}\end{array}$ & $n$ & $\begin{array}{c}\text { Data } \\
\text { Coverage }(\%)\end{array}$ \\
\hline Pre-cutting & All data & -5.8 & 13.1 & -6.0 & -64.2 & 42 & 705 & 93.6 \\
\hline Pre-cutting & After filtering & -6.0 & 13.9 & -6.7 & -64.2 & 42 & 592 & 78.6 \\
\hline Post-cutting/ Pre-fertilizing & All data & 99.8 & 131.7 & 52.4 & -54.3 & 703 & 675 & 98.7 \\
\hline Post-cutting/ Pre-fertilizing & After filtering & 138.2 & 143.7 & 97.6 & -49.2 & 703 & 393 & 57.5 \\
\hline Post-fertilizing & All data & 474.0 & 611.0 & 191.7 & -2.2 & 3821 & 970 & 99.7 \\
\hline Post-fertilizing & After filtering & 559.4 & 603.5 & 304.5 & 1.4 & 3821 & 667 & 68.6 \\
\hline
\end{tabular}

Pre-cutting: 21 May, 10:00 GMT-29 May, 06:00 GMT; Post-cutting/Pre-fertilizing: 29 May, 06:00 GMT-5 June, 06:00 GMT; Post fertilizing: 5 June 06:00 GMT-15 June, 12:00 GMT

Table 8. Standard errors (SE) and \% standard errors in the concentration and flux estimates between the 4 ammonia sampling systems according to the different management periods (for the full dataset).

\begin{tabular}{lrcc}
\hline Variable & Pre-cutting & Post-cutting & Post-fertilizing \\
\hline Mean $\chi(1 \mathrm{~m})$ & 3.22 & 4.32 & 8.38 \\
SE in $\chi(1 \mathrm{~m})$ & 0.55 & 0.81 & 1.24 \\
\% SE in $\chi(\mathbf{1 ~ m})$ & $\mathbf{1 7 . 0}$ & $\mathbf{1 8 . 7}$ & $\mathbf{1 4 . 8}$ \\
Mean $\mathrm{F}_{z}\left(z_{o}\right)$ & -5.8 & 99.8 & 474.1 \\
SE in $F_{z}\left(z_{o}\right)$ & 4.4 & 33.1 & 93.7 \\
\% SE in $\mathbf{F}_{z}\left(\mathbf{z}_{o}\right)$ & $\mathbf{7 6 . 2}$ & $\mathbf{3 3 . 2}$ & $\mathbf{1 9 . 8}$ \\
\hline
\end{tabular}

For the four different measurement systems, the relative standard error in $\chi(1 \mathrm{~m})$ was similar for the three measurement periods at $15-20 \%$. By contrast, the relative standard error in $F_{z}\left(z_{o}\right)$ varied substantially between the three measurement periods. This was as expected, with better agreement between the different ammonia analyzers being found for the periods with larger fluxes.

\subsection{Time-course of uncertainties in the mean estimates of $\chi(1 \mathbf{~ m})$ and $\mathbf{F}_{z}\left(\mathbf{z}_{o}\right)$}

The availability of up to four parallel measurements of the ammonia concentrations and fluxes enabled an assessment of the uncertainty in the mean estimates of $F_{z}\left(z_{o}\right)$ and $\chi(1 \mathrm{~m})$. The standard error (SE) of the mean 15 min values was calculated as $\sigma_{n-1} / \sqrt{ } n$, where $\sigma_{n-1}$ is the sample standard deviation and $n$ is number of estimates available for a given $15 \mathrm{~min}$ period. Hence the magnitude of the SE depended on both the level of agreement of the denuders and the number of denuders operating at a given time. The time course of the SE is presented for $F_{z}\left(z_{o}\right)$ and $\chi(1 \mathrm{~m})$ (Fig. $7 \mathrm{a}$ and b). The $\mathrm{SE}$ of the $15 \mathrm{~min}$ values in the pre-cut period with substantial bi-directional exchange was typically around $60 \%$, with absolute SE values of 10 to $20 \mathrm{ng} \mathrm{m}^{-2} \mathrm{~s}^{-1}$ (Fig. 7a). Following cutting, the errors differed diurnally with daytime SE in the flux typically $40 \%$. The $\%$ SE was smallest following

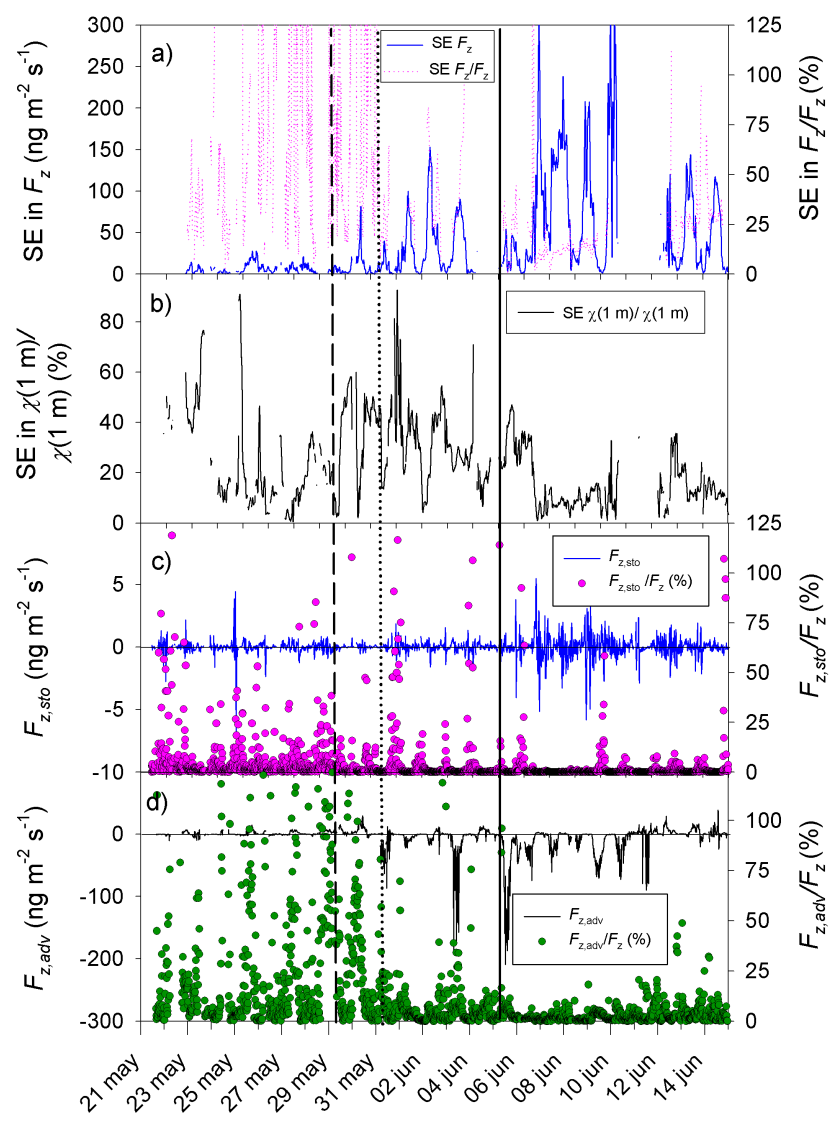

Fig. 7. Time-course of the uncertainty in mean $F_{z}\left(z_{o}\right)$ and $\chi(1 \mathrm{~m})$ presenting 1 hourly running medians of the 15 min estimates, shown together with the magnitude of advection and storage errors: (a) Percentage and absolute Standard Error (SE) in the measured ammonia flux, (b) \% SE in $\chi(1 \mathrm{~m})$, (c) absolute storage error $\left(F_{\mathrm{z}, \mathrm{sto}}\right)$ and $F_{z}$,sto as a $\%$ of $F_{z}(1 \mathrm{~m}),(\mathbf{d})$ absolute advection error $\left(F_{z \text {,adv }}\right)$, sum of the modelled advection errors at $z=1 \mathrm{~m}$ due to the experimental field and farm and $F_{z \text {,adv }}$ as a $\%$ of $F_{z}(1 \mathrm{~m})$. Vertical lines indicate cutting (dashed line), removal of the grass from the field (dotted line) and $\mathrm{NH}_{4} \mathrm{NO}_{3}$ fertilization (solid line). 
fertilization with daytime values typically $15 \%$, increasing to typically $30 \%$ from 10 June. The overall median uncertainty in the $15 \mathrm{~min}$ estimates of $\chi(1 \mathrm{~m})$ was $18 \%$, with values mostly in the range 5 to $50 \%$ (Fig. $7 \mathrm{~b}$ ). Regarding the storage and advection calculations, for much of the period these were rather small, but they were important in specific instances. The storage errors were generally less than $10 \%$ of the measured flux, although individual values occurred in the range $25-125 \%$ during periods of rapidly changing $\chi(1 \mathrm{~m})$ (Fig. 7c). The advection errors (Fig. 7d) were a similar magnitude to those for storage, with most values being less than $10 \%$ of $F_{z}$. Although larger absolute advection errors were observed post cutting and post fertilizing, the values as a percentage of the measured flux were smaller for these periods than for the pre cutting period.

\section{Discussion}

\subsection{Inter-comparison of gradient measurements}

Overall, the inter-comparison of gradient measurements was encouraging, with three of the flux measurements being within $11 \%$ of the mean estimate and the other within $32 \%$ (Table 5). There was also close agreement achieved across the concentration range, except for some days where overestimation of concentration is suspected to have occurred in some of the systems, possibly due to high operating temperatures and inaccuracies in the measurement which could be exacerbated in the large concentration range, where the calibration is no longer as robust. The inter-comparison highlighted the need for regular calibration of flux gradient systems and regular quality standard checks. As concluded by Harrison and Kitto (1990), operator differences can induce the same amount of variation in $\mathrm{NH}_{3}$ measurements as different measuring techniques and, although techniques such as AMANDA and the WEDD have been shown to be reliable in measuring $\mathrm{NH}_{3}$, operators have to be vigilant in their running of these systems. A reliable clean deionised water supply, regular changing of pump tubing and regulation of instrument operating temperature are all essential to maintain the reliability of these systems.

Having four independent systems did result in a robust final dataset with an extremely high data coverage of $\mathrm{NH}_{3}$ concentrations and fluxes of $98 \%$. The main restriction on estimates was a filter according to strict micrometeorological criteria, which reduced the flux data coverage to $69 \%$ if these filter criteria were applied. With typically 50-70\% data coverage of concentration and 30-50\% for flux being more common in other $\mathrm{NH}_{3}$ studies (e.g., Erisman et al., 1998; Sutton et al., 2001b; Horvath et al., 2005) and with the continuous record of uncertainty from the replicate systems, it is clear that this dataset is unique in coverage and robustness. As such it provides an important resource for interpretation of ammonia fluxes in relation to bioassays, models and in- teractions with other atmospheric components (Sutton et al., 2009a).

The availability of replicate instruments in the present experiment also highlight the need for caution when interpreting results from the more usual situation of a single ammonia flux detection system. Table 8 shows that the different instruments used here agreed to within $20 \%$ (standard error) for ammonia concentrations in the three management periods. By contrast, while the flux by the three systems had a standard error of $20 \%$ for the post-fertilization period (when fluxes were largest and easiest to detect), the uncertainties were larger for the pre-fertilization periods. This indicated an uncertainty of $33 \%$ for the post-cut period and $76 \%$ for the pre-cut period. As demonstrated by Fig. 2, the uncertainties can be even larger for 15 min measurements (even leading to uncertainties in flux direction). As a result, great caution is needed when interpreting such $\mathrm{NH}_{3}$ flux data when only one system is available. In this situation, it is thus essential to perform regular calibration and also zero-concentration tests (switching off air supply and checking the zero of the analyzer) and zero-flux tests (e.g. by bringing inlets to a common height and demonstrating that the measured flux is zero, Sutton et al., 1993a). Intercomparisons of measured ammonia fluxes with process models must similarly recognize the substantial uncertainty in the measured fluxes.

\subsection{Influence of management activities on $\mathrm{NH}_{3}$ flux}

The present measurements support previous findings of enhanced emissions following grass cutting (Sutton et al., 1997, 2001a; Milford et al., 2001), with a mean flux of $98 \mathrm{~g} \mathrm{Nha}^{-1}$ day $^{-1}$ after cutting compared with measurements of predominantly deposition before cutting. These emissions appear to be a consequence of altered $\mathrm{N}$ processing in the remaining sward rather than the lying cut grass (Sutton et al., 1997; David et al., 2009; Mattsson et al., 2008). The modelling of Sutton et al. (2001) and Riedo et al. (2002) explained this on the basis of a larger ammonia compensation point of the remaining plant (Riedo et al., 2002) and these interactions are further investigated by Burkhardt et al. (2009), Personne et al., (2009) and Sutton et al. (2009a).

As expected, emissions were also enhanced following fertilization, with a mean flux of $398 \mathrm{~g} \mathrm{Nha}^{-1} \mathrm{day}^{-1}$. These fluxes are somewhat larger in magnitude to those observed earlier (Sutton et al., 1997; Milford et al., 2001). Expressed as the $\%$ emission of fertilizer $\mathrm{N}$ applied, in the present case $3.2 \%$ of the $\mathrm{N}$ (applied as calcium ammonium nitrate) was lost as ammonia within 10 days of application. The emission factor for ammonium nitrate fertilizer applied to grasslands in the UK is $1.6 \%$ of the applied $\mathrm{N}$ (van der Weerden and Jarvis, 1997). By comparison using AMANDA flux measurement, Milford et al. (2001) also estimated that $1.6 \%$ of fertilizer $\mathrm{N}$ (as ammonium nitrate) was lost as ammonia from a Scottish grassland. Strictly, the value from Milford et al. (2001) is not comparable with the present study, since 
their estimate referred to total emissions (including from grass cutting). Hence if the present losses following cutting are included, this gives an equivalent loss of $3.6 \%$ of the nitrogen, further emphasizing the larger values of this study. The larger emissions measured here are possibly a result of the high temperatures which were observed, particularly in the latter period of the campaign. The mean air temperature at $1 \mathrm{~m}$ was $17.6^{\circ} \mathrm{C}$ during 5-15 June 2000 , although daily maximums reached $39^{\circ} \mathrm{C}$ (Nemitz et al., 2009b). The potential for $\mathrm{NH}_{3}$ emission increases with increasing temperature due to the dependence of solubility of $\mathrm{NH}_{3}$ on temperature, which affects the stomatal compensation point (Farquhar et al., 1980) as well as the $\mathrm{NH}_{3}$ gaseous concentration at the soil and litter surface (Nemitz et al., 2001b, 2004).

The diurnal pattern of ammonia emission following fertilization is quite typical for the changing patterns of environmental conditions, with largest fluxes occurring during the day. Substantial emission also occurred at night immediately after fertilizer application (5-6 June), demonstrating the importance of surface emissions from the soil and litter surface. However, nocturnal emissions ceased after this date, and therefore process models and other measurements (David et al., 2009) are needed to interpret the contribution of different sources and sinks.

\section{Conclusions}

An inter-comparison of four $\mathrm{NH}_{3}$ gradient measurement systems was conducted over intensively managed grassland during a four week period in May-June 2000 as part of the GRAMINAE Integrated Experiment. The inter-comparison was encouraging, with three of the flux measurements being within $11 \%$ of the mean and the other within $32 \%$. The inter-comparison highlighted the need for regular calibration of flux gradient systems and regular checks against quality standards. Operating four systems resulted in exceptionally high data coverage of measured ammonia fluxes (98\%) and provided a continuous record of the uncertainty of the data. The measurements supported previous findings of enhanced emissions from grass cutting with a mean daily flux of $98 \mathrm{~g} \mathrm{~N} \mathrm{ha}^{-1} \mathrm{day}^{-1}$ after cutting compared to measurements of predominantly deposition before cutting. Emissions were also enhanced following fertilization, with a mean flux of $398 \mathrm{~g} \mathrm{Nha}^{-1} \mathrm{day}^{-1}$. The results of this intercomparison provide a robust dataset for the evaluation of the processes controlling ammonia exchange, while indicating the need for caution in interpreting unreplicated ammonia flux measurements. It is clear that measurement of ambient ammonia concentration and flux still remains a challenge and future research should focus on continuing to improve ammonia measurement techniques and the reliability of flux measurements.
Acknowledgements. The authors gratefully acknowledge funding from the European Commission under the GRAMINAE project and from a wide range of national funding agencies, in particular the UK Defra (AEQ Division). Final synthesis of these results was conducted under the EC NitroEurope Integrated Project. The authors also gratefully acknowledge support from the Spanish Ministry of Education and Science through the Juan de la Cierva Program.

Edited by: K. Pilegaard

\section{References}

Appel, B. R., Tokiwa, Y., Kothny, E. L., Wu, R., and Povard, V.: Evaluation of procedures for measuring atmospheric nitric acid and ammonia, Atmos. Environ., 22, 1565-1573, 1988.

Blum, H., Hendrey, G., and Nosberger, J.: Effects of elevated $\mathrm{CO}_{2}$, $\mathrm{N}$ fertilization, and cutting regime on the production and quality of Lolium perenne L. shoot necromass, Acta Oecol., 18, 291295, 1997.

Burkhardt, J., Flechard, C. R., Gresens, F., Mattsson, M., Jongejan, P. A. C., Erisman, J. W., Weidinger, T., Meszaros, R., Nemitz, E., and Sutton, M. A.: Modelling the dynamic chemical interactions of atmospheric ammonia with leaf surface wetness in a managed grassland canopy, Biogeosciences, 6, 67-83, 2009, http://www.biogeosciences.net/6/67/2009/.

Bussink, D. W., Harper, L. A., and Corre, W. J.: Ammonia transport in a temperate grassland. 2. Diurnal fluctuations in response to weather and management conditions, Agron. J., 88, 621-626, 1996.

Dabney, S. M. and Bouldin, D. R., Fluxes of ammonia over an alfalfa field, Agron. J., 77, 572-578, 1985.

David, M., Roche, R., Mattsson, M., Sutton, M. A., Dämmgen, U., Schjoerring, J. K., and Cellier, P.: The effects of management on ammonia fluxes over a cut grassland as measured by use of dynamic chambers, Biogeosciences Discuss., 6, 1599-1623, 2009, http://www.biogeosciences-discuss.net/6/1599/2009/.

Denmead, O. T., Simpson, J. R., and Freney, J. R.: Ammonia flux into the atmosphere from a grazed pasture, Science, 185, 609610, 1974.

Denmead, O. T., Freney, J. R., and Simpson, J. R.: A closed ammonia cycle within a plant canopy, Soil. Biol. Biochem., 8, 161164, 1976.

Duyzer, J. H.: Dry deposition of ammonia and ammonium aerosols over heathland, J. Geophys. Res., 99, 18757-18763, 1994.

Erisman, J. W. and Wyers, G. P.: Continuous measurements of surface exchange of $\mathrm{SO}_{2}$ and $\mathrm{NH}_{3}$ : implications for their possible interaction in the deposition process, Atmos. Environ., 27, 19371949, 1993.

Erisman, J. W., Mennen, M. G., Fowler, D., Flechard, C. R., Spindler, G., Gruner, A., Duyzer, J. H., Ruigrok, W., and Wyers, G. P.: Deposition monitoring in Europe, Environ. Monit. Assessment, 53, 279-295, 1998.

Evans, D. R., Williams, T. A., Jones, S., and Evans, S. A.: The effect of cutting and intensive grazing managements on sward components of contrasting ryegrass and white clover types when grown in mixtures, J. Agr. Sci., 130, 317-322, 1998.

Famulari, D., Fowler, D., Hargreaves, K., Milford, C., Sutton, M. A., Nemitz, E., and Weston, K.: Measuring eddy-covariance 
fluxes of ammonia using tunable diode laser absorption spectroscopy, Water Air Soil Poll., Focus, 4, 151-158, 2004.

Fangmeier, A., Hadwiger-Fangmeier, A., Van der Eerden, L., and Jäger, H. J.: Effects of atmospheric ammonia on vegetation- a review, Environ. Poll., 86, 43-82, 1994.

Farquhar, G. D., Firth, P. M., Wetselaar, R., and Wier, B.: On the gaseous exchange of ammonia between leaves and the environment: determination of the ammonia compensation point, Plant Physiol., 66, 710-714, 1980.

Ferm, M.: Method for determination of atmospheric ammonia, Atmos. Environ., 13, 1385-1393, 1979.

Flechard, C. R. and Fowler, D.: Atmospheric ammonia at a moorland site, II: Long-term surface atmosphere micrometeorological flux measurements, Q. J. Roy. Meteor. Soc., 124, 759-791, 1998.

Flesch, T. K., Prueger, J. H., and Hatfield, J. L.: Turbulent Schmidt number from a tracer experiment, Agric. For. Meteorol., 111, 299-307, 2002.

Fowler, D. and Duyzer, J. H.: Micrometeorological techniques for the measurement of trace gas exchange, in: Exchange of Trace Gases Between Terrestrial Ecosystems and the Atmosphere, edited by: Endreae, M. O. and Schimel, D. S., John Wiley, New York, USA, 189-207, 1989.

Gouw, J. A., Carleton, J. H., Custer, T. G., and Fall, R.: Emissions of volatile organic compounds from cut grass and clover are enhanced by the drying process, Geophys. Res. Lett., 26, 811-814, 1999.

Gras, J. L.: A field comparison of two atmospheric ammonia sampling techniques, Tellus, 36, 38-43, 1984.

Harper, L. A., Catchpoole, V. R., Davis, R., and Weir, K. L.: Ammonia volatilisation: soil, plant, and microclimate effects on diurnal and seasonal fluctuations, Agron. J., 75, 212-218, 1983.

Harrison, R. M., Rapsomanikis, S., and Turnbull, A..: Land-surface exchange in a chemically reactive system; surface fluxes of $\mathrm{HNO}_{3}, \mathrm{HCl}$ and $\mathrm{NH}_{3}$, Atmos. Environ., 23, 1795-1800, 1989.

Harrison, R. M. and Kitto, A. M. N.: Field intercomparison of filter pack and denuder sampling methods for reactive gaseous and particulate pollutants, Atmos. Environ, 24, 2633-2640, 1990.

Hensen, A., Loubet, B., Mosquera, J., van den Bulk, W. C. M., Erisman, J. W., Dämmgen, U., Milford, C., Löpmeier, F. J., Cellier, P., Mikuška, P., and Sutton, M. A.: Estimation of $\mathrm{NH}_{3}$ emissions from a naturally ventilated livestock farm using local-scale atmospheric dispersion modelling, Biogeosciences Discuss., 6, 825862, 2009, http://www.biogeosciences-discuss.net/6/825/2009/.

Hensen, A., Nemitz, E., Flynn, M. J., Blatter, A., Jones S. K., Sørensen, L. L., Hensen, B., Pryor, S., Jensen, B., Otjes, R. P., Cobussen, J., Loubet, B., Erisman, J. W., Gallagher, M. W., Neftel, A. and Sutton, M. A.: Inter-comparison of ammonia fluxes obtained using the Relaxed Eddy Accumulation technique, Biogeosciences Discuss., 5, 3965-4000, 2008, http://www.biogeosciences-discuss.net/5/3965/2008/.

Hertel, O., Skjøth, C. A., Lofstrøm, P., Geels, C., Frohn, L. M., Ellermann, T., and Madsen, P. V.: Modelling nitrogen deposition on a local scale - A review of the current state of the art, Environ. Chem., 3, 317-337, 2006.

Horvath, L.: On the vertical flux of gaseous ammonia over water and soil surfaces, in: Deposition of Atmospheric Pollutants, edited by: Georgii, H. W. and Pankrath, J., D. Reidel, Dordrecht, The Netherlands, 17-22, 1982.

Horvath, L., Astalos, M., Fuhrer, E., Meszaros, R., and Weidinger,
T.: Measurement of ammonia exchange over grassland in the Hungarian Great Plain, Agric. For. Meteorol., 130, 282-298, 2005.

Kormann, R. and Meixner, F. X.: An analytical footprint model for non-neutral stratification, Bound.-Layer Meteor., 99, 207-224, 2001.

Kruit, R. J. W., van Pul, W. A. J., Otjes, R. P., Hofschreuder, P., Jacobs, A. F. G., and Holtslag A. A. M.: Ammonia fluxes and derived canopy compensation points over non-fertilized agricultural grassland in The Netherlands using the new gradient ammonia-high accuracy-monitor (GRAHAM), Atmos.Environ., 41, 1271-1287, 2007.

Krupa, S. V.: Effects of atmospheric ammonia $\left(\mathrm{NH}_{3}\right)$ on terrestrial vegetation: a review, Environ. Poll., 124, 179-221, 2003.

Kugler, S., Horvath, L., and Machon, A.: Estimation of nitrogen balance between the atmosphere and Lake Balaton and a semi natural grassland in Hungary, Environ. Poll., 154, 498-503, 2008.

Loubet, B., Cellier, P., Milford, C., and Sutton, M. A..: A coupled dispersion and exchange model for short-range dry deposition of atmospheric ammonia, Q. J. Roy. Meteor. Soc., 132, 1733-1763. 2006.

Loubet, B., Milford, C., Hensen, A., Dämmgen, U., Cellier, P., and Sutton, M. A.: Advection of ammonia over a pasture field, and its effect on gradient flux measurements, Biogeosciences Discuss., 6, 163-196, 2009, http://www.biogeosciences-discuss.net/6/163/2009/.

Loubet, B., Milford, C., Sutton, M. A., and Cellier, P.: Investigation of the interaction between sources and sinks of atmospheric ammonia in an upland landscape using a simplified dispersionexchange model, J. Geophys. Res. Atmos., 106, 24183-24195, 2001.

Mannheim, T., Braschkat, J., and Marschner, H.: Ammonia emissions from senescing plants and during decompostion of crop residues, (in German) Z. Pflanzenernähr. Bodenk., 160, 125-132, 1997.

Mattsson, M., Herrmann, B., David, M., Loubet, B., Riedo, M., Theobald, M. R., Sutton, M. A., Bruhn D., Neftel A., and Schjoerring J. K.: Temporal variability in bioassays of the stomatal ammonia compensation point in relation to plant and soil nitrogen parameters in intensively managed grassland, Biogeosciences, 6, 171-179, 2009, http://www.biogeosciences.net/6/171/2009/.

McNaughton, K. G.: On the kinetic energy budget of the unstable atmospheric surface layer, Boundary-Layer Meteorol., 118, 83107, 2006.

Meyers, T. P., Luke, W. T., and Meisinger, J. J.: Fluxes of ammonia and sulfate over maize using relaxed eddy accumulation, Agric. For. Meteor., 136, 203-213, 2006.

Milford, C., Hargreaves, K. J., Sutton, M. A., Loubet, B., and Cellier, P.: Fluxes of $\mathrm{NH}_{3}$ and $\mathrm{CO}_{2}$ over upland moorland in the vicinity of agricultural land, J. Geophys. Res. Atmos., 106, 24169-24181, 2001a.

Milford, C., Theobald, M. R., Nemitz, E., and Sutton, M. A.: Dynamics of ammonia exchange in response to cutting and fertilising in an intensively-managed grassland, Water, Air Soil Poll. Focus, 1, 167-176, 2001b.

Moncrieff, J. B., Massheder, J. M., de Bruin, H., Elbers, J., Friborg, T., Heusinkveld, B., Kabat, P., Scott, S., Soegaard, H., and 
Verhoef, A.: A system to measure surface fluxes of momentum, sensible heat, water vapour and carbon dioxide, J. Hydrol., 189, 589-611, 1997.

Monteith, J. L. and Unsworth, M. H.: Principles of Environmental Physics, 2nd ed., edited by: Arnold, E., New York, USA, 291 pp., 1990.

Neftel, A., Blatter, A., Otjes, R., Erisman, J. W., and Hansen. A.: State of the art REA $\mathrm{NH}_{3}$ flux measurements, in: Proc. 10th Nitrogen Workshop, Copenhagen, August 1999, II.49, Royal Veterinary and Agricultural University, Copenhagen, Denmark, 1999.

Nemitz, E., Dorsey, J. R., Flynn, M. J., Gallagher, M. W., Hensen, A., Erisman J.-W., Owen, S. M., Dämmgen, U., and Sutton, M. A.: Aerosol fluxes and particle growth above managed grassland, Biogeosciences Discuss., 6, 341-389, 2009a,

http://www.biogeosciences-discuss.net/6/341/2009/.

Nemitz, E., Flynn, M, Williams, P. I., Milford, C., Theobald, M. R., Blatter, A., Gallagher, M. W., and Sutton, M. A.: A relaxed eddy accumulation system for the automated measurement of atmospheric ammonia fluxes, Water Air Soil Poll., Focus, 1, 189-202, 2001a.

Nemitz, E., Hargreaves, K. J., Neftel, A., Loubet, B., Cellier, P., Dorsey, J. R., Flynn, M., Hensen, A., Weidinger, T., Meszaros, R., Horvath, L., Dämmgen U., Fruehauf, C., Löpmeier F. J., Gallagher, M. W., and Sutton, M. A.: Inter-comparison and assessment of turbulent and physiological exchange parameters of grassland, Biogeosciences Discuss., 6, 241-290, 2009b, http://www.biogeosciences-discuss.net/6/241/2009/.

Nemitz, E., Milford, C., and Sutton, M. A.: A two-layer canopy compensation point model for describing bi-directional biosphere/atmosphere exchange of ammonia, Q. J. Roy. Meteor. Soc., 127, 815-833, 2001b.

Nemitz, E., Sutton, M. A., Wyers, G. P., and Jongejan, P. A. C.: Gas-particle conversions above a Dutch heathland: I. Surface exchange fluxes of $\mathrm{NH}_{3}, \mathrm{SO}_{2}, \mathrm{HNO}_{3}$ and $\mathrm{HCl}$, Atmos. Chem. Phys. 4, 989-1005, 2004.

Neftel, A., Blatter, A., Gut, A., Hogger, D., Meixner, F., Ammann, C., and Nathaus, F. J.: $\mathrm{NH}_{3}$ soil and soil surface gas measurements in a triticale wheat field, Atmos. Environ., 32, 499-505, 1998.

Pain, B. F., Phillips, V. R., Clarkson, C. R., and Klarenbeek, J. V.: Loss of nitrogen through ammonia volatilization during and following the application of pig or cattle slurry to grassland, J. Sci. Food Agr., 47, 1-12, 1989.

Personne, E., Loubet, B., Herrmann, B., Mattsson, M., Schjoerring, J. K., Nemitz, E., Sutton, M. A., and Cellier, P.: SURFATM$\mathrm{NH}_{3}$ : a model combining the surface energy balance and the bi-directional exchanges of ammonia at the field scale, Biogeosciences Discuss., 6, 71-114, 2009,

http://www.biogeosciences-discuss.net/6/71/2009/.

Phillips, S. B., Arya, S. P., and Aneja, V. P.: Ammonia flux and dry deposition velocity from near-surface concentration gradient measurements over a grass surface in North Carolina, Atmos. Environ., 38, 3469-3480, 2004.

Riedo, M., Milford, C., Schmid, M., and Sutton, M. A.: Coupling soil-plant-atmosphere exchange of ammonia with ecosystem functioning in grasslands, Ecol. Model., 158, 83-110, 2002.

Schwab, J. J., Li, Y. Q., Bae, M. S., Demerjian, K. L., Hou, J., Zhou, X. L., Jensen, B., and Pryor, S. C.: A laboratory intercomparison of real-time gaseous ammonia measurement methods, Environ. Sci. Technol., 41, 8412-8419, 2007.

Seinfeld, J. H., Atmospheric Chemistry and Physics of Air Pollution, John Wiley, New York, USA, 738 pp., 1986.

Shaw, W. J., Spicer, C. W., and Kenny, D. V.: Eddy correlation fluxes of trace gases using a tandem mass spectrometer, Atmos. Environ., 32, 2887-2898, 1998.

Smith, R. S., Buckingham, H., Bullard, M. J., Shiel, R. S., and Younger, A.: The conservation management of mesotrophic (meadow) grassland in northern England. 1. Effects of grazing, cutting date and fertiliser on the vegetation of a traditionally managed sward, Grass Forage Sci., 51, 292-305, 1996a.

Smith, R.S., Corkhill, P., Shiel, R. S., and Millward, D.: The conservation management of mesotrophic (meadow) grassland in northern England. 2. Effects of grazing, cutting date, fertiliser and seed application on the vegetation of a agriculturally improved sward, Grass Forage Sci., 51, 576-588, 1996 b.

Sommer, S. G., Schjoerring, J. K., and Denmead, O. T.: Ammonia emission from mineral fertilizers and fertilized crops, Adv. Agron., 82, 557-622, 2004.

Sutton, M. A., Fowler, D., Hargreaves, K. J., and Storeton-West, R.L.: Interactions of $\mathrm{NH}_{3}$ and $\mathrm{SO}_{2}$ exchange inferred from simultaneous flux measurements over a wheat canopy, in: General Assessment of biogenic emissions and deposition of nitrogen compounds, sulphur compounds and oxidants in Europe, Proceedings of the joint CEC/BIATEX workshop, Aveiro, (Eds: Slanina, J., Angeletti, G., and Beilke, S.), Air Pollut. Res. Report 47, CEC, Brussels, 165-182, 1993a.

Sutton, M. A., Fowler, D., and Moncrieff J. B.: The exchange of atmospheric ammonia with vegetated surfaces. I: Unfertilized vegetation, Q. J. Roy. Meteor. Soc., 119, 1023-1045, 1993 b.

Sutton, M. A., Milford, C., Dragosits, U., Singles, R., Fowler, D., Ross, C., Hill, R., Jarvis, S. C., Pain, B. P., Harrison, R., Moss, D., Webb, J., Espenhahn, S. E., Halliwell, C., Lee, D. S., Wyers, G. P., Hill, J., and ApSimon, H. M.: Gradients of atmospheric ammonia concentrations and deposition downwind of ammonia emissions: first results of the ADEPT Burrington Moor experiment, in: Gaseous exchange with grassland systems, edited by: Pain, B. P. and Jarvis, S. C., CAB International, Wallingford, UK, 131-139, 1997.

Sutton, M. A., Milford, C., Nemitz, E., Theobald, M. R., Hill, P. W., Fowler, D., Schjoerring, J. K., Mattsson, M. E., Nielsen, K. H., Husted, S., Erisman, J. W., Otjes, R., Hensen, A., Mosquera, J., Cellier, P., Loubet, B., David, M., Genermont, S., Neftel, A., Blatter, A., Herrmann, B., Jones, S. K., Horvath, L., Führer, E., Mantzanas, K., Koukoura, Z., Gallagher, M., Williams, P., Flynn, M., and Riedo, M.: Biosphere-atmosphere interactions of ammonia with grasslands: experimental strategy and results from a new European initiative, Plant Soil, 228, 131-145, 2001a.

Sutton, M. A., Miners, B., Tang, Y. S., Milford, C., Wyers, G. P., Duyzer, J. H., and Fowler, D.: Comparison of low cost measurement techniques for long-term monitoring of atmospheric ammonia, J. Environ. Monit., 3, 446-453, 2001b.

Sutton, M. A., Nemitz, E., Erisman, J. W., Beier, C., Butterbach Bahl, K., Cellier, C., de Vries, W., Cotrufo, F., Skiba, U., Di Marco, C., Jones, S., Laville, P., Soussana, J. F., Loubet, B., Twigg, M., Famulari, D., Whitehead, J., Gallagher, M. W., Neftel, A., Flechard, C., Herrmann, B., Calanca, P. L., Schjoerring, J. K., Daemmgen, U., Horvath, L., Tang, Y. S., Emmett, B. A., 
Tietema, A., Peñuelas, J., Kesik, M., Brueggemann, N., Pilegaard, K., Vesala, T., Campbell, C. L., Olesen, J. E., Dragosits, U., Theobald, M. R., Levy, P., Mobbs, D. C., Milne, R., Viovy, N., Vuichard, N., Smith, J. U., Smith, P. E., Bergamaschi, P., Fowler, D., and Reis, S.: Challenges in quantifying biosphereatmosphere exchange of nitrogen species, Environ. Poll., 150, 125-139, 2007.

Sutton, M. A., Nemitz, E., Milford, C., Campbell, C., Erisman, J. W., Hensen, A., Cellier, P., David, M., Loubet, B., Personne, E., Schjoerring, J. K., Mattsson, M., Dorsey, J. R., Gallagher, M. W., Horvath, L., Weidinger, T., Meszaros, R., Dämmgen, U., Neftel, A., Herrmann, B., Lehman, B. E. Flechard, C., and Burkhardt, J.: Dynamics of ammonia exchange with cut grassland: Synthesis of results and conclusions, Biogeosciences Discuss., 6, 1121-1184, 2009a, http://www.biogeosciences-discuss.net/6/1121/2009/.

Sutton, M. A., Nemitz, E., Milford, C., Fowler, D., Moreno, J., San Jose, R., Wyers, G. P., Otjes, R., Harrison, R., Husted, S., and Schjoerring, J. K.: Micrometeorological measurements of net ammonia fluxes over oilseed rape during two vegetation periods, Agric. For. Meteorol., 105, 351-369, 2000.

Sutton, M. A., Nemitz, E., Theobald, M. R., Milford, C., Dorsey, J. R., Gallagher, M. W., Hensen, A., Jongejan, P. A. C., Erisman, J. W., Mattsson, M., Schjoerring, J. K., Cellier, P., Loubet, B., Roche, R., Neftel, A., Herrmann, B., Jones, S. K., Lehman, B. E., Horvath, L., Weidinger, T., Rajkai, K., Burkhardt, J., Löpmeier, F. J., and Dämmgen, U.: Dynamics of ammonia exchange with cut grassland: strategy and implementation of the GRAMINAE Integrated Experiment, Biogeosciences, 6, 309-331, 2009b, http://www.biogeosciences.net/6/309/2009/.

Thompson, R. B., Pain, B. F., and Lockyer, D. R.: Ammonia volatilization from cattle slurry following surface application to grassland. 1. Influence of mechanical separation, changes in chemical-composition during volatilization and the presence of the grass sward, Plant and Soil, 125, 109-117, 1990a.

Thompson, R. B., Pain, B. F., and Rees, Y. J.: Ammonia volatilization from cattle slurry following surface application to grassland. 2. Influence of application rate, wind-speed and applying slurry in narrow bands, Plant Soil, 125, 119-128, 1990b.
Trebs, I., Lara, L. L., Zeri, L. M. M., Gatti, L. V., Artaxo, P., Dlugi, R., Slanina, J., Andreae, M. O., and Meixner, F. X.: Dry and wet deposition of inorganic nitrogen compounds to a tropical pasture site (Rondonia, Brazil), Atmos. Chem. Phys., 6, 447-469, 2006, http://www.atmos-chem-phys.net/6/447/2006/.

Van der Weerden, T. J. and Jarvis, S. C.: Ammonia emission factors for $\mathrm{N}$ fertilisers applied to two contrasting grassland soils, Environ. Pollut., 95, 205-211, 1997.

Vecera, Z. and Dasgupta, P. K.: Measurement of atmospheric nitric and nitrous acids with a wet effluent diffusion denuder and low-pressure ion chromatography-post column reaction detection, Anal. Chem., 63, 2210-2216, 1991.

Walker, J. T., Robarge, W. P., Wu, Y., and Meyers, T.: Measurement of bi-directional ammonia fluxes over soybean using the modified Bowen-ratio technique, Agric. For. Meteorol., 138, 54-68. 2006.

Warland, J. S., Dias, G. M., and Thurtella, G. W.: A tunable diode laser system for ammonia flux measurements over multiple plots, Environ. Pollut., 114, 215-221, 2001.

Whitehead, D. C. and Lockyer, D. R.: Decomposing grass herbage as a source of ammonia in the atmosphere, Atmos. Environ., 23, 1867-1869, 1989.

Whitehead, J. D., Twigg, M., Famulari, D., Nemitz, E., Sutton, M. A., Gallagher, M. W., and Fowler, D.: Evaluation of laser absorption spectroscopic techniques for eddy covariance flux measurements of ammonia, Environ. Sci. Technol., 42, 2041-2046, 2008.

Wiebe, H. A., Anlauf, K. G., Tuazon, E. C., Winer, A. M., Biermann, H. W., Appel, B. R., Solomon, P. A., Cass, G. R., Ellestad, T. G., Knapp, K. T., Peake, E., Spicer, C. W., and Lawson, D. R.: A comparison of measurements of atmospheric ammonia by filter packs, transition-flow reactors, simple and annular denuders and fourier transform infrared spectroscopy, Atmos. Environ., 24, 1019-1028, 1990.

Wyers, G. P., Otjes, R. P., and Slanina, J.: A continuous flow denuder for the measurement of ambient concentrations and surface fluxes of ammonia, Atmos. Environ., 27, 2085-2090, 1993. 